\title{
DETERMINAÇÃO DA ENERGIA METABOLIZÁVEL DE GORDURAS E SUA APLICAÇÃO NA FORMULAÇÃO DE DIETAS PARA FRANGOS DE CORTE
}

\author{
Juliano Benedito Gaiotto
}

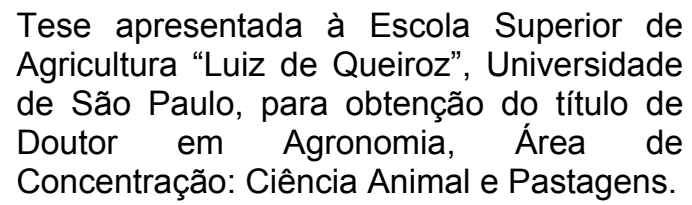

P I R A C I C A B A

Estado de São Paulo - Brasil

Julho - 2004 


\section{DETERMINAÇÃO DA ENERGIA METABOLIZÁVEL DE GORDURAS E SUA APLICAÇÃO NA FORMULAÇÃO DE DIETAS PARA FRANGOS DE CORTE}

\section{Juliano Benedito Gaiotto}

Engenheiro Agrônomo

Orientador: Prof. Dr. JOSÉ FERNANDO MACHADO MENTEN

Tese apresentada à Escola Superior de Agricultura "Luiz de Queiroz", Universidade de São Paulo, para obtenção do título de Doutor em Agronomia, Área de Concentração: Ciência Animal e Pastagens.

P I R A C I C A B A

Estado de São Paulo - Brasil

Julho -2004 

Dados Internacionais de Catalogação na Publicação (CIP)
DIVISÃO DE BIBLIOTECA E DOCUMENTAÇÃO - ESALQ/USP

Gaiotto, Juliano Benedito

Determinação da energia metabolizável de gorduras e sua aplicação na

formulação de dietas para frangos de corte / Juliano Benedito Gaiotto. -- Piracicaba, 2004.

$82 \mathrm{p}$.

Tese (doutorado) - - Escola Superior de Agricultura Luiz de Queiroz, 2004.

Bibliografia.

1. Dieta animal 2. Energia metabolizável 3. Frangos de corte 4. Gorduras 5. Metabolismo animal I. Título

CDD 636.214 


\section{Dedico}

Aos meus amados pais Luiz e Teresa, e ao meu querido irmão Daniel, pelo amor e carinho recebido em toda minha vida.

\section{Ofereço}

A Lidiane pelo amor, carinho e amizade recebido a cada dia. 


\section{AGRADECIMENTOS}

\section{A DEUS.}

Ao Prof Dr José Fernando Machado Menten pela amizade e sabedoria transmitida de forma serena e paciente durante todo caminho do aprendizado.

Ao Prof. Dr Roberto Dias de Moraes e Silva pelo apoio, compreensão e confiança desde o curso de graduação.

À fundação de Amparo à Pesquisa do Estado de São Paulo (FAPESP) pelo financiamento do projeto e pela bolsa concedida.

Aos colegas Aline, Flávio, José Otávio e Adriana pela amizade e incentivo durante todo o curso de doutorado.

A todos os professores do Departamento de Zootecnia pelos ensinamentos durante o curso de mestrado.

Às secretárias Vera e Cláudia do Departamento de Zootecnia pela amizade e ajuda em todos os momentos.

Aos funcionários do Departamento de Zootecnia, pela ajuda concedida durante estes anos. 


\section{SUMÁRIO}

Página

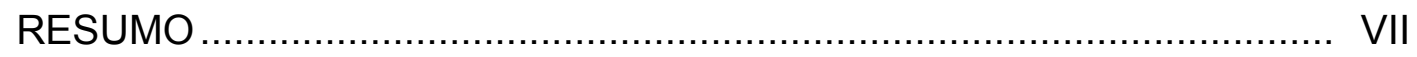

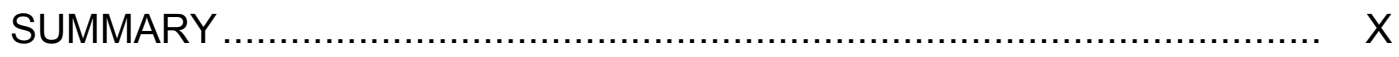

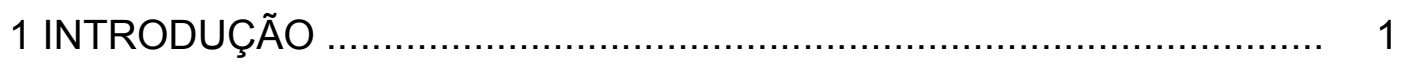

2 REVISÃO DE LITERATURA ............................................................ 3

2.1 Definição dos componentes dos óleos e gorduras ............................... 3

2.1.1 Ácidos graxos ..................................................................... 4

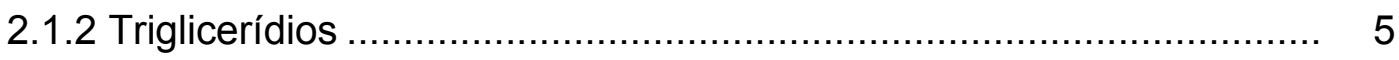

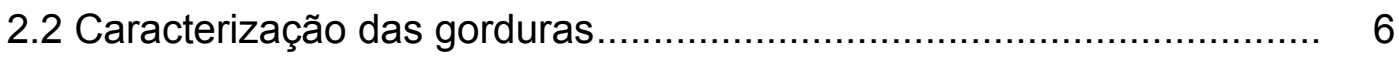

2.2.1 Óleo de soja ........................................................................

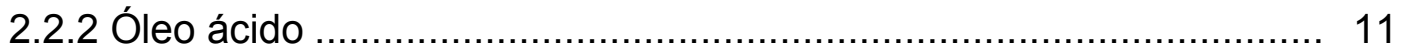

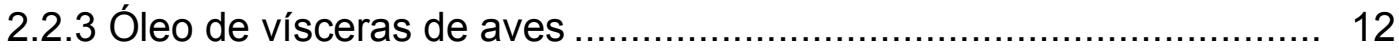

2.3 Energia metabolizável aparente das gorduras .................................. 13

2.4 Digestão e absorção das gorduras nas aves...................................... 17

2.5 Absorção de gorduras nas primeiras semanas de desenvolvimento das aves ............................................................................. 18

2.6 Os ácidos graxos livres das gorduras (AGL) ………...................... 21

2.7 Proporção de ácidos graxos saturados e insaturados .......................... 23

2.8 Rendimento de carcaça e acúmulo de gordura em frangos de corte ... 25

2.8.1 Gordura na carcaça: sexo e idade das aves ................................ 25

2.8.2 Composição da carcaça e gordura abdominal: genética ................... 27

2.8.3 Rendimento de carcaça e acúmulo de gordura: nutrição .................. 28

2.8.3.1 Relação energia-proteína ....................................................... 28

2.8.3.2 Níveis de gordura na dieta................................................... 30 
2.8.3.3 Tipo de gordura suplementada

3 DETERMINAÇÃO DA ENERGIA METABOLIZÁVEL DE GORDURAS PARA FRANGOS DE CORTE

Resumo 33

Summary 34

3.1 Introdução. 35

3.2 Material e Métodos 39

3.3 Resultados e Discussão . 45

3.4 Conclusões 51

4 AVALIAÇÃO DO DESEMPENHO E RENDIMENTOS DA CARCAÇA DE FRANGOS DE CORTE ALIMENTADOS COM DIETAS FORMULADAS COM DIFERENTES GORDURAS

Resumo 52

Summary 53

4.1 Introdução. 53

4.2 Material e Métodos 58

4.3 Resultados e Discussão 66

4.4 Conclusões. 72

5 CONCLUSÕES GERAIS 73

REFERÊNCIAS BIBLIOGRÁFICAS 74 


\title{
DETERMINAÇÃO DA ENERGIA METABOLIZÁVEL DE GORDURAS E SUA APLICAÇÃO NA FORMULAÇÃO DE DIETAS PARA FRANGOS DE CORTE
}

\author{
Autor: JULIANO BENEDITO GAIOTTO \\ Orientador: Prof. Dr JOSÉ FERNANDO MACHADO MENTEN
}

\section{RESUMO}

\begin{abstract}
Foram realizados dois experimentos de metabolismo para a determinação da energia metabolizável aparente (EMA), energia metabolizável aparente corrigida para nitrogênio (EMAn) e digestibilidade aparente (DG) de diferentes gorduras para as fases pré-inicial, inicial, crescimento e final de frangos de corte. Um terceiro experimento foi realizado para avaliar o ganho de peso, consumo de ração, conversão alimentar e viabilidade de frangos de corte alimentados com dietas suplementadas com gorduras com valores energéticos determinados no experimentos de metabolismo. Nos experimentos de metabolismo os tratamentos consistiram de uma dieta referência e 5 dietas obtidas pela substituição de $10 \%$, peso por peso, da dieta referência pelas seguintes gorduras e suas misturas: óleo de soja (OS), óleo ácido (OA), óleo de vísceras de aves (OV), 50\% de óleo de soja com $50 \%$ de óleo ácido (OS50/OA50), 50\% de óleo de soja com
\end{abstract}


$50 \%$ de óleo de vísceras de aves (OS50/OV50) no primeiro experimento e as misturas: $75 \%$ de óleo de vísceras de aves com 25\% óleo soja (OV75/OS25), $75 \%$ óleo de vísceras de aves com 25\% óleo ácido (OV75/OA25), 50\% de óleo ácido com $50 \%$ óleo de vísceras de aves (OA50/OV50), 75\% de óleo ácido com $25 \%$ óleo de vísceras de aves (OA75/OV25), 75\% de óleo ácido com $25 \%$ de óleo de soja (OA75/OS25) no segundo experimento. A dieta referência era baseada em milho e farelo de soja, formuladas sem gordura suplementar. Em cada experimento foram realizados 4 ensaios correspondentes às fases de criação. Utilizaram-se 4 repetições por tratamento em delineamento inteiramente ao acaso. No primeiro experimento os valores de EMA, EMAn e DG do OA mostraram-se inferiores $(p<0,05)$ às demais gorduras. A EMA, EMAn e a DG do OS50/OA50 e do OS50/OV50 não apresentaram diferenças $(p>0,05)$ em relação ao OV e OS nas fases pré-inicial, inicial e crescimento, porém na fase final, essas misturas resultaram em energias metabolizáveis similares ao OV, menores que o OS e superiores ao OA. A DG das dietas com misturas de gordura não diferiu $(p>0,05)$ das dietas com OS e OV em todas as fases estudadas. No experimento 2 os valores de EMA, EMAn e DG para as misturas OA75/OV25, OA75/SO25, OA50/OV50 foram inferiores as demais gorduras nas fases pré-inicial, inicial e crescimento. A EMA, EMAn e a DG do OV75/OS25 foram superiores nas fases pré-inicial, inicial e crescimento. Em ambos os experimentos, os valores de EMA e EMAn das gorduras na fase pré-inicial foram inferiores quando comparados às demais fases. No terceiro experimento utilizaram-se as mesmas fases de criação e os valores de EMAn determinados nos experimentos anteriores. Os tratamentos selecionados foram OA, OS, OV, 750A/25OS, 500A/500S e 500V/500S, com 6 repetições e 40 aves por parcela, alimentadas com rações isoprotéicas e isoenergéticas a base de milho e farelo de soja. Foram determinados o desempenho, peso e rendimento da carcaça, peito, coxa, sobrecoxa, gordura abdominal e fígado. O OS resultou em inferior desempenho, peso da 
carcaça, peito, coxa e sobrecoxa em relação aos demais tratamentos. Não houve diferenças significativas entre os tratamentos no acúmulo de gordura, peso do fígado, rendimentos da carcaça e das partes. 


\title{
APPARENT METABOLIZABLE ENERGY DETERMINATION OF FAT AND FORMULATED TO DIETS BROILER CHICKEN
}

\author{
Author: JULIANO BENEDITO GAIOTTO
}

Adviser: Prof. Dr JOSÉ FERNANDO MACHADO MENTEN

\section{SUMMARY}

Two metabolism trials were carried out to determine the apparent metabolizable energy (AME) and nitrogen-corrected apparent metabolizable energy (AMEn) of fats and their mixtures. In trial 1 the treatments consisted of a basal diet and 5 diets obtained by substituting, weight by weight, $10 \%$ of the basal diets with the fat sources: soybean oil (SO), acidulated soapstock (AS), poultry offal fat (PF), $50 \%$ soybean oil and $50 \%$ acidulated soapstock (SO50/AS50), $50 \%$ soybean oil and $50 \%$ poultry offal fat (SO50/PF50). In trial 2 , the following mixtures were fed: $75 \%$ poultry offal fat and $25 \%$ soybean oil (PF75/SO25), $75 \%$ poultry offal fat and $25 \%$ acidulated soapstock (PF75/AS25), 50\% soapstock and 50\% poultry offal fat (AS50/PF50), $75 \%$ acidulated soapstock and $25 \%$ poultry offal fat (AS75/PF25) and $75 \%$ 
acidulated soapstock and $25 \%$ soybean oil (AS75/SO25). The basal diet was based on corn and soybean meal, formulated with no added fat. Each treatment was replicated 4 times in a completely randomized design. In each trial there were 4 assays corresponding to the pre-starter (0-10 days), starter (11-21 days), grower (22-35 days) and finisher (36-42 days) phases. In trial 1, AME and AMEn values for AS were lower $(p<0.05)$ than those for the other fats in all phases; this can be due to the elevated level of free fatty acids in AS. AME and AMEn of the mixture SO50/AS50, as well as the mixture (SO50/PF50), were not different from those of SO and PF in the pre-starter, starter and grower phases; however, in the finisher phase these mixtures resulted in metabolizable energy similar to PF $(p>0.05)$, lower than SO and higher than AS $(p<0.05)$. In trial $2, A M E$ and $A M E n$ values were lower in the pre-starter, starter and grower phases for the mixtures AS75/PF25, AS75/SO25 and AS50/SO50 ( $p<0.05)$. AME and AMEn were higher for PF75/SO25 in the pre-starter, starter and grower phases $(p<0.05)$. In both trials the metabolizable energy was lower for birds in the pre-starter phase than in the other phases. In a performance trial diets were formulated using the AMEn of fats previously determined for pre-starter, starter, grower and finisher phases. Selected treatments were AS, SO, PF, AS75/SO25, AS50/SO50 and PF50/SO50 with 6 replicates and 40 birds per pen. Diets were isoproteic and isoenergetic. Growth performance and carcass and parts yield were determined. Treatments did not result in significant differences ( $p>0.05)$, except for SO which was inferior to the other treatments. 


\section{INTRODUÇÃO}

Os óleos e gorduras são dotados de propriedades nutricionais, funcionais e organolépticas. A propriedade priorizada na industria avícola é a nutricional, com destaque para o fornecimento de energia na forma concentrada. Em segundo plano, mas não menos importante, o fornecimento de ácidos graxos essenciais, colesterol e vitaminas lipossolúveis (Dziezak, 1989).

Para simplificar a nomenclatura e unificar os termos, será atribuído aos óleos e às gorduras o termo genérico gorduras, porém com distinções entre ambos quando necessário.

Nas rações, veículo pelo qual se fornece gordura às aves, algumas propriedades agregadoras de qualidade serão destacadas quando se utilizam gorduras: primeiramente o fornecimento pelas gorduras de energia na forma concentrada, que em média apresenta $9,4 \mathrm{kcal} / \mathrm{g}$ de energia bruta, superior a energia das proteínas e dos carboidratos; é fornecedora de ácidos graxos essenciais nas formulações de rações para frangos de corte; facilita a absorção de vitaminas lipossolúveis pelas aves e altera algumas características físicas das rações, como a redução da poeira emitida nas fábricas, transporte e galpões, bem como aumento da vida útil de equipamentos pela redução de atritos (Rutz, 1994).

A energia metabolizável aparente (EMA) é uma das maneiras de dimensionar a parcela da energia ingerida (EI) a ser utilizada pelas aves. Para tanto o uso adequado de gorduras nas rações requer o conhecimento 
preciso dos valores individuais da energia metabolizável das gorduras. Formulações de rações que utilizam valores de energia errôneos sejam estes superestimados ou subestimados, refletem diretamente no desenvolvimento, na qualidade da carcaça e no custo de produção das aves.

Inúmeros fatores levam a determinações equivocadas da EMA, principalmente aqueles que interferem na absorção das gorduras aves, como a relação de ácidos graxos saturados e insaturados, maior concentração de ácidos graxos livres, idade das aves, linhagem e níveis de suplementação das gorduras nas dietas.

Assim, a finalidade deste trabalho foi determinar os valores de energia metabolizável aparente, energia metabolizável aparente corrigida para nitrogênio e digestibilidade aparente da gordura da dieta do óleo de soja, óleo ácido, óleo de vísceras de aves e suas misturas em diferentes proporções, na fase pré-inicial (0-7 dias de idade), inicial (8-21 dias), crescimento (22-35 dias) e final (36-42 dias) e sua influência no consumo de ração, ganho de peso, conversão alimentar, viabilidade e rendimento da carcaça de frangos de corte. 


\section{REVISÃO DE LITERATURA}

Os lipídios são formados por unidades estruturais com predominante hidrofobicidade, sendo uma característica única para esta classe de componentes. Os lipídios são grupos de substâncias químicas heterogêneas insolúveis em água e solúveis em solventes, tais como clorofórmio, éter de petróleo ou álcoois (Gurr \& Harwood, 1991; Hyvönen, 1996). A insolubilidade em água é a propriedade analítica primordial usada como base para facilitar a separação dos lipídios das proteínas e carboidratos.

Os óleos e gorduras referem-se a uma classe específica de lipídios formandos por ácidos graxos, responsáveis pela estocagem de energia em animais e vegetais (Nelson \& Cox, 2000). A diferença básica entre óleos e gorduras está na forma física à temperatura ambiente $\left(22^{\circ} \mathrm{C}\right)$ : líquida para óleos e sólida, ou pastosa, para as gorduras (Dziezak, 1989).

Os termos óleos e gorduras serão simplesmente referidos como gorduras, terminologia utilizada pela maioria da indústria avícola brasileira, porém suas diferenças serão especificadas quando necessário.

\subsection{Definição dos componentes dos óleos e gorduras}

Os principais componentes dos óleos e gorduras são divididos em dois grupos: componentes maiores, que correspondem aos triglicerídios e componentes menores, destacando-se os diglicerídios, monoglicerídios, ácidos graxos livres, fosfolipídios, esteróis, ceras, colesterol e vitaminas lipossolúveis (Gunstone, 1994; Hyvönen, 1996). Os componentes maiores 
juntamente com os diglicerídios, monoglicerídios, ácidos graxos livres e fosfolipídios estão diretamente ligados ao fornecimento de energia para aves.

\subsection{1 Ácidos graxos}

Os ácidos graxos são compostos pelo grupo carboxílico ligado a uma cadeia carbônica. São as unidades básicas de formação dos triglicerídios juntamente com o glicerol, classificados como saturados e insaturados. Os ácidos graxos saturados são caracterizados pela ausência de duplas ligações na cadeia hidrocarbônica, conferindo-lhes a forma de cadeia linear de carbonos. Os ácidos graxos insaturados possuem uma ou mais duplas ligações entre os carbonos. À medida que as duplas ligações aumentam, maior é a curvatura da cadeia (Gurr \& Harwood, 1991).

Algumas características físicas dos ácidos graxos influenciam diretamente as características dos óleos e gorduras. O tamanho da cadeia carbônica e a presença de ligações duplas alteram o ponto de fusão dos ácidos graxos. Quanto maior o número de carbonos na cadeia dos ácidos graxos, sejam estes saturados ou insaturados, maior será o ponto de fusão. No entanto, a presença de uma ou mais duplas ligações reduz o ponto de fusão (Tabela 1).

As características relacionadas ao ponto de fusão apresentadas pelos ácidos graxos são transferidas para os óleos e gorduras. Na temperatura ambiente, a forma líquida dos óleos é reflexo da predominante composição dos ácidos graxos insaturados, enquanto as gorduras se caracterizam pela viscosidade ou solidez, reflexo da elevada concentração dos ácidos graxos saturados de cadeia longa.

Tabela 1. Ponto de fusão de alguns ácidos graxos saturados e insaturados 


\begin{tabular}{|c|c|c|c|}
\hline $\begin{array}{l}\mathrm{N}^{\circ} \text { de carbonos e } \\
\text { duplas ligações }\end{array}$ & Nome sistemático & Nome comum & $\begin{array}{l}\text { Ponto fusão } \\
\left({ }^{\circ} \mathrm{C}\right)\end{array}$ \\
\hline $12: 0$ & n-Dodecanóico & Láurico & 42,2 \\
\hline $14: 0$ & $n$-Tetradecanóico & Mirístico & 52,1 \\
\hline $16: 0$ & $n$-Hexadecanóico & Palmítico & 60,7 \\
\hline $18: 0$ & n- Octadecanóico & Esteárico & 69,6 \\
\hline $18: 1$ & cis-9-Octadecenóico & Oléico & 16,3 \\
\hline $18: 2$ & $\begin{array}{c}\text { cis,cis-9,12- } \\
\text { Octadecadienóico }\end{array}$ & Linoléico & $-6,5$ \\
\hline $18: 3$ & $\begin{array}{l}\text { cis,cis, cis-9,12,15- } \\
\text { Octadecatrienóico }\end{array}$ & Linolênico & $-12,8$ \\
\hline $20: 4$ & $\begin{array}{c}\text { cis,cis, cis,cis- } \\
5,8,11,14- \\
\text { Icosatetraenóico }\end{array}$ & Araquidônico & $-49,5$ \\
\hline
\end{tabular}

Fonte: DziezaK (1989); Gurr \& Harwood (1991); Nelson \& Cox (2000)

\subsubsection{Triglicerídios}

Os triglicerídios são os principais constituintes dos óleos e gorduras, formados a partir da ligação éster de três ácidos graxos a um glicerol (Zambiazi et al., 2000). A ligação éster do carbono central do glicerol ao ácido graxo é convencionalmente chamada de ligação 2 , enquanto as ligações dos carbonos adjacentes são chamadas de 1 e 3 (Gurr \& Harwood, 1991; Nelson \& Cox, 2000). A distribuição dos ácidos graxos nas ligações 1 , 2 e 3 do glicerol, mais especificamente no óleo de soja, segue algumas regras quando são arranjados. Primeiro, os ácidos graxos com cadeias 
maiores que 18 carbonos, ácido graxo palmítico e esteárico, são distribuídos igualmente e aleatoriamente nas posições 1 e 3 . O segundo passo é a distribuição igual e aleatória dos ácidos graxos oléico e linoléico em todas as posições 3 restantes e finalmente, todas as posições são preenchidas pelo ácido linoléico (Liu, 1999). As diferenças na distribuição dos ácidos graxos no glicerol das gorduras, influenciam na absorção dos ácidos graxos, principalmente aqueles ligados ao glicerol na posição 2 (Tabela 2). Segundo Renner \& Hill (1961), a absorção do ácido graxo palmítico ligado ao glicerol na posição 2 é maior do que quando o mesmo ácido graxo se encontra nas demais posições da gordura suína, Ihe conferindo uma diferenciação na utilização da energia desta gordura.

Tabela 2. Distribuição dos ácidos graxos no óleo de soja, gordura de frango e gordura suína

\begin{tabular}{lcccccccc}
\hline \multirow{2}{*}{ Gorduras } & \multirow{2}{*}{ Posição } & \multicolumn{7}{c}{ Ácidos graxos (mol\%) } \\
& & $14: 0$ & $16: 0$ & $16: 1$ & $18: 0$ & $18: 1$ & $18: 2$ & $18: 3$ \\
\hline Óleo de & 1 & - & 13,8 & - & 5,9 & 22,9 & 48,4 & 9,1 \\
soja & 2 & - & 0,9 & - & 0,3 & 21,5 & 69,7 & 7,1 \\
& 3 & - & 13,1 & - & 5,6 & 28,0 & 45,2 & 8,4 \\
Gordura & 1 & 2,0 & 25,0 & 12,0 & 6,0 & 33,0 & 14,0 & 2,0 \\
de & 2 & 1,0 & 15,0 & 7,0 & 4,0 & 43,0 & 23,0 & 3,0 \\
frango & 3 & 1,0 & 14,0 & 12,0 & 6,0 & 35,0 & 14,0 & 2,0 \\
Gordura & 1 & 2,0 & 16,0 & 3,0 & 21,0 & 44,0 & 12,0 & 1,0 \\
suína & 2 & 4,0 & 59,0 & 4,0 & 3,0 & 17,0 & 8,0 & 1,0 \\
& 3 & 1,0 & 2,0 & 3,0 & 10,0 & 65,0 & 24,0 & 1,0 \\
\hline
\end{tabular}

Fonte: Gunstone et al.(1994)

\subsection{Caracterização das gorduras}

Apesar da diferença na forma física dos óleos e gorduras, a indústria avícola atribui a ambos o termo genérico "gorduras". As principais gorduras utilizadas 
na formulação de rações para frangos de corte são: óleo de soja, óleo ácido, gordura suína, óleo de vísceras de aves e sebo bovino. No entanto, serão descritas apenas as gorduras de relevância para este trabalho.

\subsection{1 Óleo de soja}

O processo de obtenção do óleo bruto, degomado e refinado de soja é dividido em três partes: preparação para extração do óleo, extração mecânica ou por solvente e refinação.

Segundo Liu (1999), a preparação para extração do óleo de soja inicia-se com a remoção das impurezas da massa de grãos através do peneiramento, visando melhorar a qualidade da massa de grãos e reduzir o desgaste de equipamentos. Em seguida, os grãos limpos são submetidos à secagem até atingir 10 a $11 \%$ de umidade. O processo de secagem dos grãos deve ser realizado numa temperatura ao redor de $80^{\circ} \mathrm{C}$ durante $20-30 \mathrm{~min}$, mas devido ao volume de produção estar concentrado num período do ano e os equipamentos de secagem trabalharem na capacidade máxima para a otimização dos custos, na prática a temperatura de secagem varia entre 100 a $140^{\circ} \mathrm{C}$ com tempos menores. O processamento da soja segue para a preparação ou para a armazenagem.

Um dos processos utilizados para extração de óleo de soja é o mecânico, constituído de uma extrusora para a desativação dos fatores antinutricinais do grão de soja. Este processo é realizado pela elevação da temperatura produzida pelo atrito do grão com eixo interno e o cilindro externo, formando uma pasta que é direcionada a uma prensa expeller para extração de parte do óleo, originando a soja semi-integral e o óleo bruto de soja.

Outro processo mais eficiente de extração de óleo é por solvente. O processo inicia-se com o descascamento, através do rápido aquecimento da superfície com temperaturas acima de $85^{\circ} \mathrm{C}$, levando a queda abrupta de umidade da casca e conseqüentemente seu desprendimento do grão. Logo 
após, os grãos são submetidos à quebra em 4 a 8 fragmentos a fim de se obter uma completa exposição das células na laminação.

O próximo passo é o condicionamento, que consiste no aquecimento dos fragmentos a $60-70^{\circ} \mathrm{C}$ à umidade de 9 a $11 \%$ para obter plasticidade para a laminação.

A laminação é realizada por rolos dentados mantidos sob pressão hidráulica para produzir lâminas entre 0,25 a 0,37 $\mathrm{mm}$. Este processo facilita a extração do óleo através do fluxo de solvente pelas lâminas e do rompimento das células do cotilédone ricas em óleo.

Na seqüência, as lâminas são submetidas ao processo de expansão, através do expansor, equipamento formado por uma rosca parafuso num cano com elevada temperatura, pressão e umidade. Esse processo leva à expansão das lâminas, reduzindo a utilização de solvente na extração e facilitando a dessolventização do farelo.

A segunda parte do processo consiste na extração do óleo por solvente. As propriedades do solvente ideal são a seletividade para triglicerídios, não deixar resíduo tóxico no óleo, baixa temperatura de vaporização, não reagir com os grãos e equipamentos, além de não ser inflamável, não explodir, ser barato e disponível em grandes quantidades. $\mathrm{O}$ solvente comercialmente utilizado para extração de óleo de soja é o hexano, que atende à maioria dos requisitos de um solvente ideal, porém é explosivo, inflamável e caro.

O processo de extração por hexano consiste na penetração seletiva do solvente nos corpos lipídicos do cotilédone, solubilização do óleo e difusão do óleo-hexano para fora dos mesmos. O tempo de extração vai depender da espessura das lâminas e da umidade que possuem, pois estes interferem diretamente no coeficiente de difusão. $O$ aumento no tempo de extração leva a um aumento da extração de componentes menores e fosfolipídios. 
A solução de óleo e hexano são chamadas de micela, contém 70 a $75 \%$ de óleo e 25 a $29 \%$ de hexano. A micela é submetida ao processo de separação por diferença no ponto de ebulição do óleo e do hexano. A partir do óleo bruto inicia-se a terceira parte de processamento do óleo chamada de refinação. O processo de refinação está dividido em degomação, neutralização, clareamento e deodorização.

A degomação é o processo de remoção dos fosfolipídios do óleo bruto de soja, realizado pela adição de 1 a $3 \%$ de água a $70^{\circ} \mathrm{C}$ que atrai os fosfolipídios polares separando-os da fase óleo. Neste processo, são obtidos o óleo degomado e a lecitina. O óleo bruto e o óleo degomado de soja são os mais utilizados nas dietas de frangos de corte.

A neutralização é o processo seguinte de refinação do óleo e consiste na remoção dos ácidos graxos livres do óleo degomado (Ruiz-Méndez, et al.,1997). Os ácidos graxos são removidos pela adição do hidróxido de sódio. Há a saponificação dos ácidos graxos livres e remoção por centrifugação, além da remoção de alguns triglicerídios, fosfolipídios e pigmentos. Neste processo há a formação do óleo refinado, porém não totalmente processado, e do resíduo "soapstock" que originará o ácido graxo de óleo de soja pelo processo de acidificação.

Após a neutralização o óleo refinado passa pelo processo de clareamento e deodorização para finalmente ser embalado e comercializado.

Na Tabela 3, são apresentadas as concentrações componentes encontrados antes e após o refino do óleo de soja.

Tabela 3. Composição do óleo bruto e óleo refinado de soja

\begin{tabular}{llll}
\hline Componentes Óleo bruto Unidade & Óleo refinado \\
\hline
\end{tabular}




\begin{tabular}{lccc}
\hline Triglicerídios & $\%$ & $95-97$ & $>99$ \\
Fosfolipídios & $\%$ & $1,5-2,5$ & $0,003-0,045$ \\
Ácidos graxos livres & $\%$ & $0,3-0,7$ & $<0,05$ \\
Matéria insaponificável & $\%$ & 1,6 & 0,3 \\
Ferro & ppm & $1-3$ & $0,1-0,3$ \\
Cobre & ppm & $0,03-0,05$ & $0,02-0,06$ \\
\hline
\end{tabular}

Fonte: Liu (1999)

$\mathrm{Na}$ Tabela 4, são apresentados os perfis dos ácidos graxos do óleo de soja de acordo com alguns autores, mostrando que os processos de extração procuram padronizar o óleo, tornando fácil sua classificação.

O perfil de ácidos graxos do óleo de soja é caracterizado pela alta concentração de ácidos graxos polinsaturados (linoléico e linolênico).

Tabela 4. Perfis dos ácidos graxos do óleo de soja

\begin{tabular}{lccc}
\hline \multirow{2}{*}{ Ácidos graxos } & \multicolumn{3}{c}{ \% ácidos graxos totais } \\
& Ketels \& De & Zollitsch et al. & Liu \\
& Groote (1989) & $(1997)$ & $(1999)$ \\
\hline 16:0 (palmítico) & 10,7 & 10,4 & 11,0 \\
18:0 (esteárico) & 1,8 & 3,7 & 4,0 \\
18:1 (oléico) & 22,3 & 21,6 & 23,4 \\
18:2 (linoléico) & 51,9 & 50,6 & 53,2 \\
18:3 (linolênico) & 7,0 & 11,8 & 7,8 \\
Saturados & 12,6 & 14,5 & 15,2 \\
Insaturados & 81,3 & 84,2 & 84,5 \\
Polinsaturados & 58,9 & 62,4 & 61,0 \\
\hline
\end{tabular}




\subsection{2 Óleo ácido}

O processo de neutralização do óleo degomado tem como resíduo o "soapstock", que consiste em sais orgânicos de sódio formados a partir da reação entre ácidos graxos livres com hidróxido de sódio. Depois de retirado o "soapstock", este passa pelo processo de acidificação através da adição de ácido sulfúrico ou ácido fosfórico, revertendo o processo de saponificação dos ácidos graxos livres com hidróxido de sódio.

A quantidade de ácidos graxos livres a ser retirada do óleo dependerá do processo de extração, do grau de conservação do grão e das condições de estocagem, pois condições adversas favorecem a hidrólise do triglicerídios e aumento de ácidos graxos livres. Além disso, o processo de degomagem do óleo pode interferir na neutralização do óleo quando as gomas não são retiradas adequadamente, causando emulsificação do óleo carregando-o para "soapstock". O óleo carregado pela goma dificulta a hidrólise do "soapstock" pelo ácido sulfúrico para formar o óleo ácido.

Como o "soapstock" é considerado um resíduo para as plantas processadoras, mistura-se o "soapstock" do óleo de soja aos provenientes dos demais grãos processados, tais como, girassol, canola e milho, para posterior transformação em óleo ácido.

Com este procedimento, a composição dos ácidos graxos do óleo ácido é extremamente variada, dificultando sua classificação e padronização (Tabela 5). 
Tabela 5. Perfil dos ácidos graxos do óleo ácido

\begin{tabular}{lcc}
\hline \multirow{2}{*}{ Ácidos graxos } & \multicolumn{2}{c}{$\%$ ácidos graxos totais } \\
& Young (1961) & Renner \& Hill (1961) \\
\hline 16:0 (palmítico) & 12,3 & 19,2 \\
18:0 (esteárico) & 4,5 & 4,6 \\
18:1 (oléico) & 30,0 & 17,6 \\
18:2 (linoléico) & 46,7 & 51,2 \\
18:3 (linolênico) & 6,4 & 7,1 \\
Saturados & 16,8 & 23,8 \\
Insaturados & 83,1 & 75,9 \\
Polinsaturados & 56,6 & 58,3 \\
\hline
\end{tabular}

\subsection{3 Óleo de vísceras de aves}

O óleo de vísceras de aves é obtido a partir da produção da farinha de vísceras de frango. A farinha de vísceras e o óleo de vísceras de aves, na maioria dos abatedouros avícolas são originárias das vísceras, pés, cabeças, restos do processo de separação mecânica da carne e aves condenadas pelos serviços oficiais de inspeção. Os resíduos são direcionados ao setor de subprodutos, para serem processados no digestor.

O digestor para processamento das vísceras é um cilindro revestido com chapas de aço espessas, compartimentos de carga e descarga, pás giratórias internas e entrada para vapor de água. Neste processo, o tempo de cocção, a pressão e a temperatura de funcionamento interferem diretamente na qualidade da farinha de vísceras e do óleo de vísceras de aves (Maffi, 1993).

Após o processamento, todo conteúdo do digestor é descarregado num percolador, separando as vísceras do óleo e da água. As vísceras seguem para uma prensa expeller para a separação do restante do óleo. O óleo e a água do percolador passam por tanques de lavagem para serem separadas. O óleo dos tanques de lavagem se junta à gordura proveniente da prensa 
expeller, para serem filtrados e armazenados em tanques (Neto, 1994). O perfil dos ácidos graxos contidos no óleo de vísceras de aves é apresentado na Tabela 6.

O perfil de ácidos graxos do óleo de vísceras de aves, quando comparada ao do óleo de soja, possui maior porcentagem dos ácidos graxos palmítico e oléico, e inferior porcentagem dos ácidos graxos linoléico e linolênico. $\mathrm{O}$ diferencial marcante entre as gorduras é a presença do ácido graxo palmitoléico apenas no óleo de vísceras de aves.

Tabela 6. Perfil dos ácido graxos do óleo de vísceras de aves

\begin{tabular}{lcc}
\hline \multirow{2}{*}{ Ácidos graxos } & \multicolumn{2}{c}{ \% ácidos graxos totais } \\
& Brue \& Latshaw (1985) & Waldroup et al. (1995) \\
\hline 16:0 (palmítico) & 26,8 & 23,2 \\
16:1 (palmitoleico) & 9,0 & 7,1 \\
18:0 (esteárico) & 2,4 & 6,4 \\
18:1 (oléico) & 42,9 & 43,0 \\
18:2 (linoléico) & 16,9 & 17,9 \\
18:3 (linolênico) & 0,9 & 0,6 \\
Saturados & 30,3 & 31 \\
Insaturados & 69,7 & 69,2 \\
Polinsaturados & 17,8 & 18,5 \\
\hline
\end{tabular}

\subsection{Energia metabolizável aparente das gorduras}

A energia metabolizável aparente (EMA) é uma das maneiras de dimensionar a parcela da energia ingerida (EI) a ser utilizada pelas aves. A partição da energia ingerida pelas aves até a energia metabolizável aparente é descrita na Figura 1. 


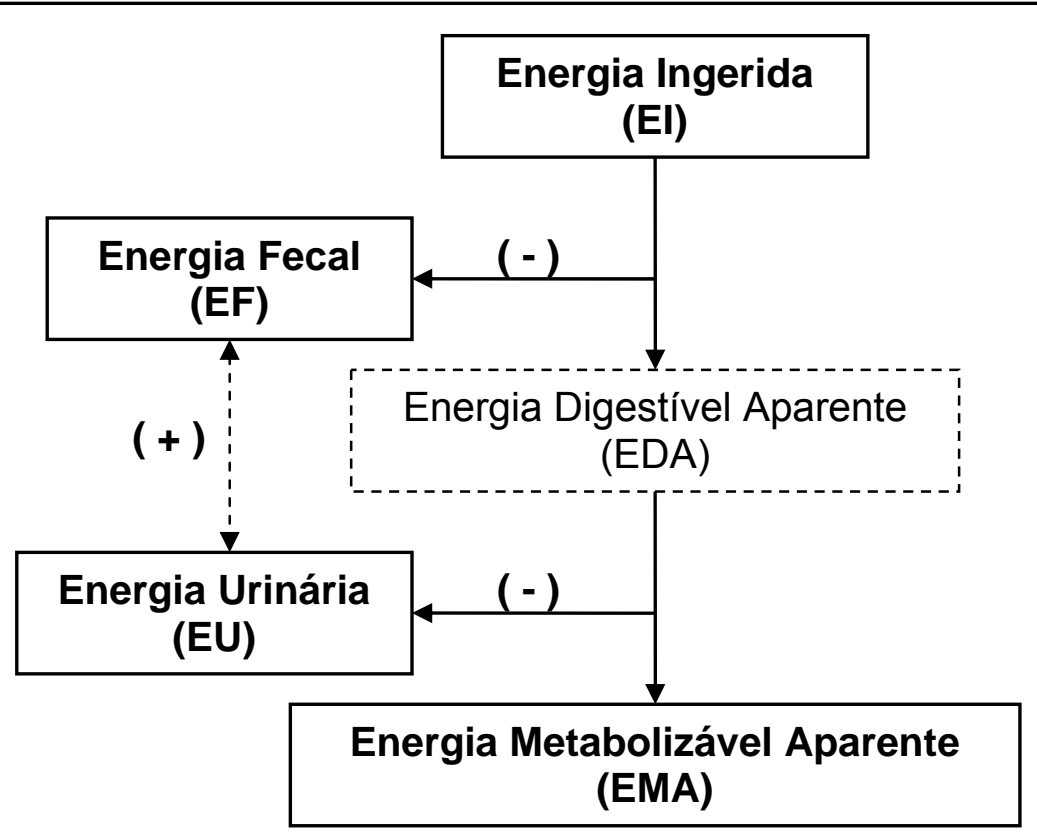

Figura 1- Partição da energia ingerida

Fonte: Sibbald (1982)

A partição da energia ingerida inicia-se com a subtração da energia fecal, para originar a energia digestível aparente. Nas aves a urina e fezes são excretadas juntas, assim para a determinação da energia digestível é necessário realizar uma cirurgia para separação das fezes ou uma coleta do conteúdo ileal terminal após abate das aves. No entanto, a energia metabolizável é determinada diretamente com a coleta das excretas.

Segundo Sibbald (1982), o método básico para mensurar a energia metabolizável aparente e energia metabolizável aparente corrigida para nitrogênio consiste na determinação da energia contida na dieta ingerida subtraindo-se a energia contida nas fezes e urina excretada.

Vários fatores podem influenciar na determinação da energia da gordura, entre estes, o nível de inclusão de gordura nas dietas, o tipo de dieta utilizada, ambiente, sexo, genética, sanidade, etc. 
O nível de inclusão de gorduras nas dietas pode influenciar de dois modos à determinação da energia. Primeiramente, através do aumento da energia metabolizável, à medida que se suplementa mais gordura nas dietas (Young \& Artman, 1961). O aumento na digestibilidade e na energia metabolizável das gorduras à medida que se eleva o nível de inclusão de gordura na dieta também foi observado por Sibbald \& Slinger (1963), Mateos \& Sell (1980), Mateos \& Sell (1981), Wiseman et al. (1986), Ketels \& De Groote (1988) e Wiseman \& Salvador (1989).

O segundo modo é pelo erro experimental, que é maior em rações com menor porcentagem de gordura substituída nas dietas. Sibbald \& Slinger (1963) mostraram que, para cada $100 \mathrm{kcal}$ EM/kg de erro na determinação de energia da dieta, resultará numa variação de 1.000 kcal EM/kg no valor atribuído à gordura, quando se utiliza apenas $10 \%$ desta na dieta. Utilizandose $50 \%$ de gordura na dieta, a variação na energia desta será em torno de $200 \mathrm{kcal}$ EM/kg. Portanto, para se terem resultados confiáveis de determinação de energia metabolizável, é necessário a substituição altos níveis de gordura na dieta experimental, sem que haja redução do consumo de ração pelas aves.

As variações de determinação de energia influenciadas pelo tipo de dieta basal foram descritas por Sibbald \& Kramer (1980a), que utilizaram duas dietas, uma base de trigo e outra à base de milho. Estas foram suplementadas com $5 \%$ de sebo bovino e os valores apresentados foram: $7.390 \mathrm{kcal} E M / \mathrm{kg}$ para o sebo bovino na dieta à base de trigo e $8.740 \mathrm{kcal}$ EM/kg para o sebo bovino na dieta à base de milho. Ainda Sibbald \& Kramer (1980b), agora utilizando 8 tipos de dietas basais, fizeram a determinação da energia metabolizável do sebo bovino, suplementado 4,5\% na dieta. Estes apresentaram que as diferenças energéticas variam de 7800 a $8260 \mathrm{kcal}$ $\mathrm{EM} / \mathrm{kg}$ de sebo bovino.

Toda discussão anterior mostra a enorme variação na absorção das gorduras e na determinação da energia metabolizável, tornando difícil a 
comparação dos valores determinados. Na Tabela 7, estão apresentados os valores de energia metabolizável determinados por diferentes autores, conforme a idade e o nível de inclusão de sebo bovino na dieta das aves.

Tabela 7. Valores de energia metabolizável (EM) determinados por diferentes pesquisadores, variando o nível de inclusão de sebo bovino na dieta e a idade das aves

\begin{tabular}{lccc}
\hline \multicolumn{1}{c}{ Autores } & $\begin{array}{c}\text { Idade } \\
\text { (semanas) }\end{array}$ & $\begin{array}{c}\text { Inclusão na dieta } \\
(\%)\end{array}$ & $\begin{array}{c}\text { EM } \\
(\mathrm{kcal} / \mathrm{kg})\end{array}$ \\
\hline Young et al. (1961) & $3-4$ & 15 & 6.560 \\
Young et al. (1961) & $7-8$ & 15 & 6.920 \\
Sibbald et al. (1961) & $2-3$ & 10 & 6.400 \\
Sibbald et al. (1961) & $2-3$ & 20 & 7.460 \\
Artman (1964) & $7-8$ & 15 & 7.320 \\
NRC (1994) & - & 10 & $7.268-7.780^{1}$ \\
Rostagno et al. (2000) & - & - & 7.436 \\
\hline
\end{tabular}

1-Vários valores atribuídos ao sebo dependendo de sua composição.

Rostagno et al. (2000) apresentaram o valor de $8.790 \mathrm{kcal} / \mathrm{kg}$ de energia metabolizável aparente para óleo de soja, diferente dos resultados apresentados por Cardoso et al. (2000) e Andreotti et al. (2000) com valores de $8.331 \mathrm{kcal} / \mathrm{kg}$ e $9.201 \mathrm{kcal} / \mathrm{kg}$, respectivamente.

As mesmas variações nos resultados foram detectadas na energia metabolizável aparente do óleo de vísceras de aves, com os valores de 8817 $\mathrm{kcal} / \mathrm{kg}$ (Rostagno et al., 2000), $8.545 \mathrm{kcal} / \mathrm{kg}$ (Cardoso et al., 2000) e 8.251 $\mathrm{kcal} / \mathrm{kg}$ (Andreotti et al., 2000).

Segundo Artman (1964), o valor de energia metabolizável do óleo ácido é $8.130 \mathrm{kcal} / \mathrm{kg}$, diferente dos valores encontrado por Zumbado et al. (1999) de $8.349 \mathrm{kcal} / \mathrm{kg}$ e $8.598 \mathrm{kcal} / \mathrm{kg}$ para diferentes dietas basais. 


\subsection{Digestão e absorção das gorduras nas aves}

A digestão das gorduras no trato digestório das aves, mais especificamente no duodeno, realiza-se pela ação da lipase, colipase e sais biliares. Os sais biliares, juntamente com os fosfolipídios promovem a formação de gotículas de gordura, com aproximadamente $5000 \AA \hat{~ d e ~ d i a ̂ m e t r o, ~ e ~ o ~ a l i n h a m e n t o ~ d o s ~}$ triglicerídios na interface água-óleo (Tuchweber et al., 1996). Com os triglicerídios alinhados, expõe-se para fase aquosa os ácidos graxos esterificados ao glicerol nas posições 1 e 3, onde agirão a colipase e a lipase (Pignol et al., 1998). A colipase, proteína de baixo peso molecular, secretada pelo pâncreas, liga-se à interface água-óleo e permite a conexão da lipase na gotícula de gordura (van Tilbeurgh et al., 1992, 1993, 1999). Neste momento, a lipase, devido à sua especificidade, age primeiro na ligação 1 dos diglicerídios e, posteriormente, nas ligações 1 e 3 dos triglicerídios, hidrolisando-os a ácidos graxos livres e monoglicerídios (Winkler et al., 1990). Após a hidrólise, os ácidos graxos livres e os monoglicerídios, ligados à gotícula de gordura, são projetados para a fase aquosa do conteúdo intestinal e participaram da formação de micelas de gordura (Nelson \& Cox, 2000; Lesson \& Summer, 2001; Macari et al., 2002).

As micelas são formadas espontaneamente na interface água-óleo por ácidos graxos de cadeia média, ácidos graxos insaturados de cadeia longa, fosfolipídios, monoglicerídios e sais biliares, para haver maior superfície de contato dos componentes da gordura com os enterócitos. O diâmetro de uma micela estável varia de 30 a $100 \AA$ (Krogdahl, 1985; Lesson \& Summers, 2001).

O núcleo hidrofóbico das micelas solubiliza os ácidos graxos saturados de cadeia longa, diglicerídios, vitaminas lipossolúveis e ésteres de colesterol. A capacidade de solubilização do núcleo hidrofóbico é dependente de seus elementos formadores, principalmente da concentração de ácidos graxos insaturados e fosfolipídios no intestino delgado. Este fato 
influencia diretamente a absorção dos elementos solubilizados no núcleo hidrofóbico (Krogdahl, 1985; Lesson \& Summers, 2001).

As micelas aproximam-se das microvilosidades e seus elementos são absorvidos pelos enterócitos. Para tal, faz-se necessário a atuação da proteína ligadora de ácidos graxos (FABP), responsável pelo transporte dos ácidos graxos das microvilosidades para o citosol dos enterócitos (Katongole \& March, 1980; Macari et al., 2002). Na mucosa intestinal, os ácidos graxos livres e monoglicerídios são ressintetizados a triglicerídios e juntamente com vitaminas e ésteres de colesterol são incorporadas às apoproteínas para formar os quilomicrons (ou portomicrons), que são levados diretamente para o fígado (nas aves), através do sistema portal.

\subsection{Absorção de gorduras nas primeiras semanas de desenvolvimento} das aves

A capacidade fisiológica das aves limita a absorção de gorduras na fase inicial de vida destas. Nos primeiros dias pós-nascimento, os frangos de corte tem reduzida capacidade de absorção de gordura, como determina Carew et al. (1972) através de um experimento de digestibilidade da gordura da dieta com a suplementação de óleo de milho e sebo bovino. Os valores determinados da digestibilidade da gordura da dieta para ambas as gorduras foram inferiores na primeira semana (2 a 7 dias) em relação à segunda semana (8 a 15 dias) de vida dos frangos de corte machos (Tabela 8). Posteriormente, Wiseman \& Salvador (1989) detectaram menor digestibilidade do sebo bovino e de uma mistura de óleos vegetais adicionados à dieta aos 10 dias em relação aos 25 dias de idade. Os resultados dos trabalhos anteriores foram ratificados por Mossab et al. (2000) que mostraram o aumento da digestibilidade aparente dos ácidos graxos totais e individuais do óleo de soja e sebo bovino da primeira para a terceira semana de idade (Tabela 9). 
Tabela 8. Digestibilidade de diferentes gorduras em frangos de corte na primeira e segunda semana de idade

Idade (semanas)

Digestibilidade (\%)

Óleo de milho

Sebo bovino

\begin{tabular}{ccc}
\hline 1 & $84^{\mathrm{b}}$ & $40^{\mathrm{b}}$ \\
2 & $95^{\mathrm{a}}$ & $78^{\mathrm{a}}$ \\
\hline
\end{tabular}

Fonte: Carew et al. (1972)

a,b Diferem estatisticamente na mesma coluna $(P<0,02)$

Tabela 9. Digestibilidade aparente dos ácidos graxos do óleo de soja (OS) e do sebo bovino (SB), na primeira e terceira semanas de idade

\begin{tabular}{ccccccccccc}
\hline & \multicolumn{8}{c}{ Digestibilidade aparente dos ácidos graxos (\%) } \\
Idade & \multicolumn{1}{c}{ Totais } & Palmítico & Esteárico & Oléico & \multicolumn{2}{c}{ Linoléico } \\
sem. & OS & SB & OS & SB & OS & SB & OS & SB & OS & SB \\
\hline 1 & $86,4^{\mathrm{b}}$ & $41,9^{\mathrm{b}}$ & $81,8^{\mathrm{b}}$ & $35,4^{\mathrm{b}}$ & $72,5^{\mathrm{b}}$ & $5,5^{\mathrm{b}}$ & $84,6^{\mathrm{b}}$ & $65,5^{\mathrm{b}}$ & $88,5^{\mathrm{b}}$ & $57,3^{\mathrm{b}}$ \\
3 & $95,7^{\mathrm{a}}$ & $64,0^{\mathrm{a}}$ & $94,2^{\mathrm{a}}$ & $53,9^{\mathrm{a}}$ & $87,5^{\mathrm{a}}$ & $30,9^{\mathrm{a}}$ & $95,3^{\mathrm{a}}$ & $87,4^{\mathrm{a}}$ & $96,7^{\mathrm{a}}$ & $95,3^{\mathrm{a}}$ \\
\hline
\end{tabular}

Fonte: Mossab et al.(2000)

${ }^{a, b}$ Diferem estatisticamente na mesma coluna $(P<0,05)$

Reflexos da digestibilidade da gordura da dieta são observados na utilização da energia neste período. Wiseman \& Salvador (1989) verificaram o mesmo comportamento, já descrito anteriormente para a digestibilidade da gordura da dieta, na energia metabolizável da dieta. Mossab et al. (2000) determinaram a energia metabolizável aparente das gorduras na primeira e terceira semana de idade e verificaram elevação dos valores do óleo de soja e sebo bovino com a idade (Tabela 10). 
Tabela 10. Energia metabolizável aparente (EMA) de gorduras em diferentes idades

\begin{tabular}{ccc}
\hline $\begin{array}{c}\text { Idade } \\
\text { (semanas) }\end{array}$ & EMA (kcal/kg) \\
\hline 1 & $8.158^{\mathrm{b}}$ & Sebo bovino \\
\hline 3 & $9.029^{\mathrm{a}}$ & $3.966^{\mathrm{b}}$ \\
& & $6.051^{\mathrm{a}}$ \\
\hline
\end{tabular}

Fonte: Mossab et al. (2000)

${ }^{a, b}$ Diferem estatisticamente na mesma coluna $(P<0,001)$

A reduzida absorção de gordura na fase inicial de desenvolvimento das aves é caracterizada pela inferior capacidade de produção de lipase pancreática e sais biliares pelos órgãos envolvidos na digestão. Gomez \& Polin (1976) determinaram a importância dos ácidos biliares na absorção do sebo bovino aos 7 dias de idade e concluíram que a adição de 0,025\% e 0,050\% do ácido cólico, quenodesoxicólico e taurocólico aumentaram a absorção de gordura, entretanto sem alterar o ganho de peso, conversão alimentar e energia metabolizável da dieta. Noy \& Sklan (1995) determinaram que a secreção de sais biliares em frangos de corte aumentou em 10 vezes no período de 4 a 21 dias de idade. Os mesmos autores ainda quantificaram a secreção de lipase, tripsina e amilase pancreática e observaram um aumento de 20,50 e 100 vezes, respectivamente, na secreção destas enzimas neste período. Noy \& Sklan (2000) ainda demonstraram que a concentração de lipase era 5 vezes menor em relação à tripsina e à amilase no intestino delgado, aos 7 dias de idade. Isto indica uma baixa produção pós-nascimento e o lento aumento na secreção dos elementos responsáveis pela digestão da gordura.

Além da influência dos sais biliares e das lipases na digestão e absorção de gorduras, há ainda a ação da proteína ligadora de ácidos graxos (FABP) no enterócitos. Katongole \& March (1980) relacionaram a concentração da FABP no intestino, com absorção de gordura em duas 
raças e uma linhagem de frangos (Tabela 11). Houve efeito da concentração da FABP em relação à gordura utilizada nas dietas e nas raças que absorveram diferentemente a gordura.

Tabela 11. Digestibilidade aparente da gordura da dieta com sebo bovino e óleo de milho e concentração de FABP no intestino de duas raças e uma linhagem de frango aos 7 dias de idade

\begin{tabular}{|c|c|c|c|}
\hline \multirow{2}{*}{ Raças e linhagem } & \multicolumn{2}{|c|}{ Digestibilidade da gordura da dieta (\%) } & \multirow{2}{*}{$\mathrm{FABP}(\mathrm{mg} / \mathrm{g})$} \\
\hline & Sebo bovino & Óleo de milho & \\
\hline New Hampshire & $90,1^{a}$ & $91,0^{a}$ & $28,3^{a}$ \\
\hline White Leghorn & $85,0^{a}$ & $91,0^{\mathrm{a}}$ & $25,3^{a}$ \\
\hline Frango de corte & $71,7^{\mathrm{b}}$ & $89,3^{a}$ & $16,3^{b}$ \\
\hline
\end{tabular}

Fonte: Katongole \& March (1980)

${ }^{a, b}$ Diferem estatisticamente na mesma coluna $(P<0,05)$

Penz Jr. e Vieira (1998) não recomendam a utilização de altos níveis de gorduras na dieta pré-inicial de frangos de corte, pois a gordura não digerida no trato digestivo favoreceria a oxidação e sua excreção excessiva, além de reduzir a taxa de passagem e favorecer a utilização dessa energia por microrganismos prejudiciais ao desenvolvimento das aves. No entanto, Wiseman et al. (1986) incluíram óleo de soja e sebo bovino (1,5\% a 15\%), com acréscimos de $1,5 \%$ às dietas e obtiveram um aumento linear na energia metabolizável aparente da dieta aos 14 dias de idade. O acréscimo linear na energia metabolizável da dieta com a inclusão de gordura foi confirmado por Wiseman \& Salvador (1989).

\subsection{Os ácidos graxos livres das gorduras (AGL)}

Os processos de digestão e absorção das gorduras são prejudicados com a presença, no intestino, dos AGL. Algumas gorduras caracterizam-se pelos elevados níveis de AGL, como é o caso das gorduras hidrolisadas e 
dos resíduos do processo de neutralização dos óleos. A ação dos $A G L$ influenciando a absorção das gorduras foi descrita por Young (1961), que utilizou o óleo de milho como controle, uma mistura de óleo vegetal e gordura animal hidrolisada, contendo $40 \%$ de AGL e uma mistura de gordura animal hidrolisada mais óleo ácido de soja, contendo 95\% de AGL. Este autor verificou que a digestibilidade da gordura da dieta com óleo de milho foi de $91,4 \%$, enquanto que a da mistura que continha $40 \%$ de AGL foi de $81,1 \%$, e que continha $95 \%$ de $A G L$ foi de $69,6 \%$, na $4^{\text {a }}$ semana de idade das aves.

Da mesma forma, Wiseman \& Salvador (1991) utilizaram sebo bovino, óleo de palma e óleo de soja, misturados com seus óleos ácidos em diferentes proporções. Foram obtidos vários níveis de AGL e determinou-se a digestibilidade da gordura da dieta para os diferentes produtos. Ocorreu a redução na digestibilidade da gordura da dieta à medida que aumentava os níveis de AGL fornecidos às aves (Tabela 12).

Tabela 12. Variação da digestibilidade de algumas fontes de gordura, com o aumento de ácidos graxos livres (AGL) em relação aos triglicerídios (TG)

\begin{tabular}{cccc}
\hline TG/AGL & Sebo bovino & $\begin{array}{c}\text { Digestibilidade (\%) } \\
\text { Óleo de palma }\end{array}$ & Óleo de soja \\
\hline $100: 0$ & 82 & 84 & 95 \\
$75: 25$ & 81 & 83 & 94 \\
$50: 50$ & 78 & 77 & 93 \\
$25: 75$ & 75 & 74 & 91 \\
$0: 100$ & 70 & 72 & 88 \\
\hline
\end{tabular}

Fonte: Wiseman \& Salvador (1991)

Posteriormente, Blanch et al. (1995), utilizando óleo de soja e misturas de 1:1 de sebo com óleo de soja ou com óleo ácido de soja, obtiveram maiores valores de digestibilidade da gordura da dieta e energia metabolizável para o 
óleo de soja e a mistura sebo e óleo de soja, ambos diferindo significativamente $(p<0,01)$ da mistura sebo e óleo ácido de soja. (Tabela 13).

Tabela 13. Digestibilidade e energia metabolizável (EM) de algumas fontes de gordura

\begin{tabular}{lcc}
\hline Gordura & Digestibilidade (\%) & EM (kcal/kg) \\
\hline Óleo de soja & $94,03^{\mathrm{a}}$ & $8.830^{\mathrm{a}}$ \\
Óleo de soja + sebo & $89,36^{\mathrm{a}}$ & $8.363^{\mathrm{a}}$ \\
Óleo ácido + sebo & $81,47^{\mathrm{b}}$ & $7.540^{\mathrm{b}}$ \\
\hline
\end{tabular}

Fonte: Blanch et al. (1995)

${ }^{a, b}$ Diferem estatisticamente na mesma coluna $(P<0,01)$

Confirmando os resultados apresentados anteriormente, Vila \& Garcia (1996) mostraram que a digestibilidade e a energia metabolizável são reduzidas com o aumento dos níveis de ácidos graxos livres nas fontes de gordura.

Waldroup et al. (1995) utilizaram duas misturas de gordura animal e vegetal para obter diferentes níveis de AGL, 29,8\% e 44,7\%, porém não obtiveram diferenças significativas no desempenho das aves aos 42 dias de idade, provavelmente devido aos baixos níveis de AGL utilizados nas dietas das aves. Eicher et al. (2004) suplementaram frangos de corte machos com óleo de soja e óleo ácido e não verificaram diferenças significativas no ganho de peso, consumo alimentar e conversão alimentar aos 42 dias de idade.

\subsection{Proporção de ácidos graxos saturados e insaturados}

A proporção dos ácidos graxos saturados e insaturados têm papel fundamental no processo de absorção de gorduras. Segundo Renner \& Hill (1961), os ácidos graxos saturados palmítico e esteárico tiveram uma absorção de $30 \%$ e $20 \%$, respectivamente, quando presentes em uma 
mistura contendo $50 \%$ de ácidos graxos insaturados fornecida na dieta de frangos. Quando se passou para 62\% de ácidos graxos insaturados na mistura a absorção do palmítico e esteárico foi elevada para $51 \%$ e $36 \%$ e com $76 \%$ de ácidos graxos insaturados a absorção foi de $84 \%$ e $78 \%$.

Sibbald et al. (1961) misturaram $50 \%$ de óleo soja, que continha $15 \%$ dos ácidos graxo palmítico e esteárico e $84,5 \%$ dos ácidos graxos oléico, linoléico e linolênico, com $50 \%$ de sebo bovino, que continha $44 \%$ de ácidos graxos palmítico e esteárico, $49,1 \%$ de oléico, linoléico e linolênico, e observaram o aumento da digestibilidade do sebo misturado em relação ao sebo como fonte única de gordura em rações de frangos.

Artman (1964) obteve diferenças significativas $(p<0,05)$ na digestibilidade do óleo de soja, quando comparado com óleo ácido de soja, sebo bovino e mistura de 1:1 entre sebo e óleo ácido de soja quando adicionados em 15\% à ração das aves. A digestibilidade do óleo de soja foi de $95 \%$, enquanto a do óleo ácido foi de $86,2 \%$, do sebo, $68,2 \%$ e da mistura, $87 \%$.

Young \& Garrett (1963) mostraram que a mistura de fontes ricas em ácidos graxos palmítico $(\mathrm{P})$ e oléico $(\mathrm{O})$ aumentou em $10 \%$ a absorção de ácidos graxos saturados, quando a proporção $O: P$ foi de 1,34:1 em comparação à proporção $0,8: 1$, concluindo que há uma facilitação da absorção de ácidos graxos saturados em presença de ácidos graxos insaturados. Posteriormente, Gaiotto et al. (2000) constataram que frangos de corte, alimentados com a mistura de sebo bovino e óleo de soja, tiveram maior ganho de peso e melhor conversão alimentar em relação ao sebo bovino isoladamente.

A melhoria da absorção de ácido graxos saturados, obtida com as misturas de gordura, explica a obtenção do ganho energético, pois os valores obtidos de energia metabolizável são maiores que a média aritmética dos valores individuais dos componentes da mistura (Ketels \& De Groote, 1989; Zumbado et al., 1999). Os mecanismos, que influenciam a maior absorção de ácidos graxos saturados e promovem um ganho energético, não foram ainda 
elucidados, mas uma das hipóteses é a adequação do perfil de ácidos graxos para melhor absorção.

\subsection{Rendimento de carcaça e acúmulo de gordura em frangos de corte}

A avaliação da qualidade da carcaça de frangos de corte é uma forma de ratificar o efeito dos resultados obtidos em experimentos de nutrição. Os ganhos significativos de desempenho não significam melhores rendimentos de carcaças e das suas partes. O desequilíbrio nutricional dos ingredientes protéicos e energéticos resulta em maior acúmulo de gordura e perda de rendimento da carcaça.

Inúmeros fatores, apesar de serem descritos isoladamente, se interrelacionam com o rendimento de carcaça e o acúmulo de gordura na carcaça de frangos, tais como sexo, idade, genética e nutrição.

\subsubsection{Gordura na carcaça: sexo e idade das aves}

As diferentes característica de deposição de gordura por frangos machos e fêmeas foram exaustivamente estudadas. As fêmeas possuem processos fisiológicos específicos de maturação para atividade reprodutiva, acumulando mais gordura em relação aos machos, levando a um menor rendimento de carcaça. Na Figura 2 é mostrada a deposição de gordura nos dois sexos de frangos de corte, verificando que a gordura acumulada na carcaça de fêmeas é maior em relação aos machos e se acentua à medida que avança a idade. 


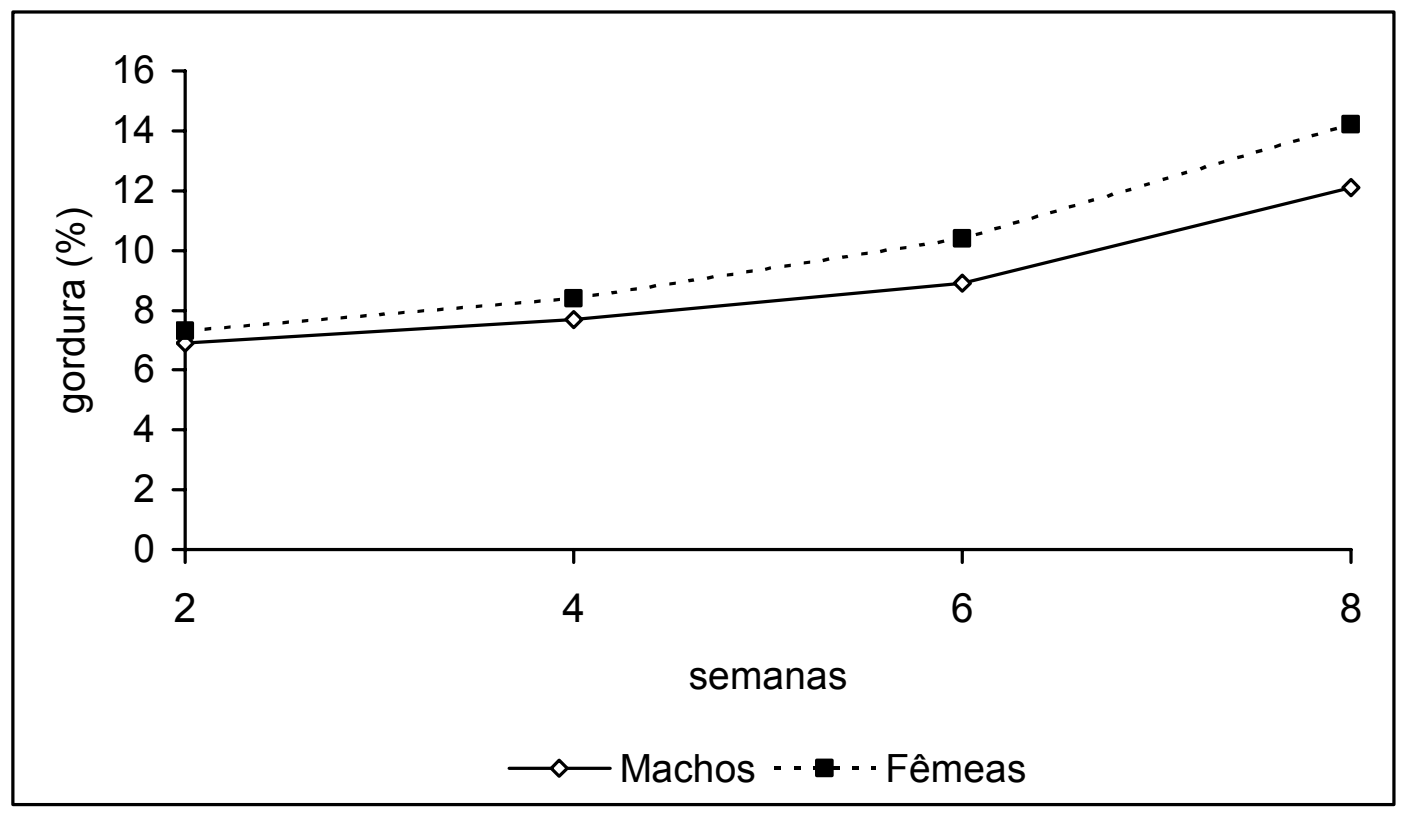

Figura 2 - Comportamento relativo da gordura acumulada na carcaça em relação à idade em frangos de corte machos

Fonte:Edwards, et al. (1973)

Deaton \& Lott (1985) verificaram idêntico comportamento da gordura abdominal de fêmeas em relação aos machos, dos 36 aos 54 dias de idade (Tabela 14).

Tabela 14. Peso vivo (PV), conversão alimentar (CA) e acúmulo de gordura abdominal (GA) em frangos de corte em diferentes idades

\begin{tabular}{ccccccc}
\hline $\begin{array}{c}\text { Idade } \\
\text { (dias) }\end{array}$ & PV $(\mathrm{g})$ & $\mathrm{CA}$ & $\mathrm{GA}(\%)$ & $\mathrm{PV}(\mathrm{g})$ & $\mathrm{CA}$ & $\mathrm{GA}(\%)$ \\
\hline 36 & $1.258^{\mathrm{d}}$ & $1,76^{\mathrm{a}}$ & $1,73^{\mathrm{a}}$ & $1.093^{\mathrm{d}}$ & $1,78^{\mathrm{a}}$ & $1,87^{\mathrm{a}}$ \\
42 & $1.667^{\mathrm{c}}$ & $1,83^{\mathrm{b}}$ & $1,88^{\mathrm{b}}$ & $1.416^{\mathrm{c}}$ & $1,87^{\mathrm{b}}$ & $2,10^{\mathrm{b}}$ \\
48 & $1.978^{\mathrm{b}}$ & $1,97^{\mathrm{c}}$ & $2,04^{\mathrm{c}}$ & $1.676^{\mathrm{b}}$ & $2,03^{\mathrm{c}}$ & $2,30^{\mathrm{c}}$ \\
54 & $2.231^{\mathrm{a}}$ & $2,10^{\mathrm{d}}$ & $2,15^{\mathrm{d}}$ & $1.922^{\mathrm{a}}$ & $2,18^{\mathrm{d}}$ & $2,56^{\mathrm{d}}$ \\
\hline
\end{tabular}

Fonte: Deaton \& Lott (1985)

a,b,c,d diferem estatisticamente nas colunas $(p<0,05)$ 
É visível a inferior deposição de gordura abdominal de machos em relação a fêmeas com reflexos diretos na conversão alimentar, evidenciando um sincronismo entre aumento de peso, gordura abdominal acumulada e idade as aves, com diferenciação no rendimento da carcaça e suas partes.

\subsubsection{Composição da carcaça e gordura abdominal: genética}

A composição e o acúmulo de gordura na carcaça de frangos de corte sofre influência direta da linhagem utilizada na criação. Keren-Zvi et al (1990) utilizaram duas linhagens selecionadas para elevado acúmulo de gordura (EA) e baixo acúmulo de gordura (BA) na carcaça. O ganho de peso, o consumo de ração e a conversão alimentar não foram diferentes estatisticamente entre as linhagens EA e BA. No entanto, a concentração de gordura em vários tecidos da carcaça foi alterada significativamente (Tabela 15).

Tabela 15. Concentração (g de gordura/100g de tecido) em diferentes tecidos, determinados para linhagem elevada gordura e baixo gordura

\begin{tabular}{lcccc}
\hline Linhagem & Abdominal & Fígado & Pele & Peito \\
\hline Elevada Gordura & 72,5 & 6,15 & 36,2 & 1,06 \\
Baixa Gordura & 67,5 & 5,67 & 32,1 & 0,86 \\
Probabilidade & $\mathrm{p}<0,001$ & $\mathrm{NS} *$ & $\mathrm{p}<0,05$ & $\mathrm{NS}^{*}$ \\
\hline
\end{tabular}

Fonte: Keren-Zvi et al (1990)

* não significativo

O acúmulo de gordura em diferentes regiões da carcaça de frangos de corte é evidente e determinante pela seleção genética das aves, influenciando a composição da carcaça (Tabela 16). 
Tabela 16. Composição da carcaça ( $\mathrm{g} / \mathrm{kg}$ de peso vivo) para linhagem elevada gordura e baixo gordura

\begin{tabular}{lcccc}
\hline Linhagem & Água & Lipídios & Proteína & Cinzas \\
\hline Elevada Gordura & 680 & 111 & 174 & 34,0 \\
Baixa Gordura & 694 & 92 & 180 & 34,1 \\
Probabilidade & $\mathrm{p}<0,001$ & $\mathrm{p}<0,001$ & $\mathrm{p}<0,01$ & $\mathrm{NS}^{*}$ \\
\hline
\end{tabular}

Fonte: Keren-Zvi et al (1990)

* não significativo

Os lipídios acumulados na carcaça da linhagem EA estão atrelados ao menor acúmulo de proteína e retenção de água pelas aves, refletindo diretamente no rendimento da carcaça e suas partes.

\subsubsection{Rendimento de carcaça e acúmulo de gordura: nutrição}

A nutrição exerce influência direta no rendimento de carcaça, partes e na gordura acumulada nas aves, através da relação energia-proteína das dietas, os níveis de gordura suplementados nas dietas e o pelo efeito específico do tipo de gordura suplementado nas dietas.

\subsubsection{Relação energia-proteína}

As características da carcaça relacionadas ao acúmulo de gordura estão diretamente relacionadas à relação energia-proteína das dietas fornecidas aos frangos de corte. Dutra Jr. et al. (1991) determinaram o desempenho e avaliaram o acúmulo de gordura na carcaça de frangos de corte alimentados com diferentes relações energia-proteína, através da suplementação de vários níveis de gordura (Tabelas 17 e 18). 
Tabela 17. Consumo de ração $(\mathrm{CR})$, ganho de peso (GP) e conversão alimentar (CA) de frangos de corte alimentados com diferentes relações energia-proteína pela suplementação de óleo de vísceras de aves (OV) de 1 a 49 dias de idade

\begin{tabular}{ccccc}
\hline OV $(\%)$ & Energia-proteína & CR $(\mathrm{g})$ & GP $(\mathrm{g})$ & CA \\
\hline 0 & 158,3 & $3.816^{\mathrm{a}}$ & $1.782^{\mathrm{c}}$ & $2,15^{\mathrm{a}}$ \\
2 & 166,3 & $3.840^{\mathrm{a}}$ & $1.833^{\mathrm{bc}}$ & $2,10^{\mathrm{a}}$ \\
4 & 171,4 & $3.791^{\mathrm{a}}$ & $1.857^{\mathrm{b}}$ & $2,04^{\mathrm{ab}}$ \\
6 & 176,4 & $3.915^{\mathrm{a}}$ & $1.896^{\mathrm{ab}}$ & $2,07^{\mathrm{ab}}$ \\
8 & 181,2 & $3.784^{\mathrm{a}}$ & $1.940^{\mathrm{a}}$ & $1,96^{\mathrm{b}}$ \\
\hline
\end{tabular}

Fonte: Dutra Jr. et al. (1991)

${ }^{a, b, c}$ Diferem estatisticamente na mesma coluna $(p<0,01)$

O estreitamento da relação energia-proteína resultou em um inferior ganho de peso, acompanhado pela piora da conversão alimentar. A dieta com pior conversão alimentar não continha suplementação de gordura. À medida que a suplementação aumentou a conversão alimentar reduziu.

Tabela 18. Acúmulo de gordura abdominal de frangos de corte alimentados com dietas com diferentes relações energia-proteína de 1 a 49 dias de idade

\begin{tabular}{ccc}
\hline Energia-proteína & \multicolumn{2}{c}{ Gordura Abdominal } \\
& $(\mathrm{g})$ & $(\%)$ \\
\hline 158,3 & $28,0^{\mathrm{c}}$ & $1,42^{\mathrm{c}}$ \\
166,3 & $37,1^{\mathrm{bc}}$ & $1,80^{\mathrm{bc}}$ \\
171,4 & $39,3^{\mathrm{bc}}$ & $1,91^{\mathrm{abc}}$ \\
176,4 & $52,4^{\mathrm{a}}$ & $2,47^{\mathrm{a}}$ \\
181,2 & $48,9^{\mathrm{ab}}$ & $2,28^{\mathrm{ab}}$ \\
\hline
\end{tabular}

Fonte: Dutra Jr. et al.(1991)

${ }^{a b c}$ Diferem estatisticamente na mesma coluna $(p<0,01)$ 
No entanto, observa-se que o estreitamento da relação energia-proteína reduz a quantidade de gordura abdominal acumulada na carcaça de frangos de corte. Ficou evidente que o aumento da suplementação de gordura na dieta melhorou a conversão alimentar, mas aumentou o acúmulo de gordura abdominal em frangos de corte.

\subsubsection{Níveis de gordura na dieta}

A influência dos níveis de gordura na dieta no acúmulo de gordura foi determinada por Junqueira et al. (2002), utilizando-se dietas isocalóricas e isoproteínas com alteração apenas no nível de inclusão de óleo de soja nas dietas, procedimento diferente adotado por Dutra Jr. et al. (1991) (Tabela 19).

Tabela 19. Rendimento de carcaça (RC), rendimento de peito (RP), rendimento de coxa+sobrecoxa (RCSC), e gordura abdominal (GA) em frangos de corte de 42 dias com quatro níveis de óleo de soja

\begin{tabular}{cccccc}
\hline Características & \multicolumn{5}{c}{ Níveis de óleo de soja } \\
$(\%)$ & 0,0 & 3,3 & 6,6 & 9,9 & CV (\%) \\
\hline RC & 68,0 & 68,0 & 67,7 & 67,5 & 1,69 \\
RP & 34,9 & 34,4 & 34,7 & 34,3 & 3,79 \\
RCSC & 31,3 & 31,9 & 31,4 & 30,9 & 4,11 \\
GA $^{*}$ & 1,92 & 2,34 & 2,56 & 2,40 & 24,20
\end{tabular}

Fonte: Junqueira et al. (2002)

* efeito quadrático $(p<0,05)$

O rendimento de carcaça e suas parte não foram influenciados pelos níveis de gorduras suplementados, apenas a gordura abdominal teve um efeito quadrático, mas sem nenhuma explicação plausível para tal efeito. Nota-se 
que a suplementação de gordura, mesmo em níveis baixos, eleva o acúmulo de gordura na carcaça quando comparadas à dieta sem suplementação.

\subsubsection{Tipo de gordura suplementada}

A suplementação de diferentes gorduras nas dietas de frangos de corte foi avaliada por Crespo \& Esteve-Garcia (2001) e mostrou-se influente no acúmulo de gordura. No entanto, estes autores não utilizaram dietas isoenergéticas e isoproteícas, corrigida a energia metabolizável para as gorduras utilizadas (Tabela 20).

Tabela 20. Ganho de peso (GP), consumo de ração (CR), conversão alimentar (CA) e acúmulo de gordura abdominal (GA) de frangos de corte alimentados com dietas contendo vários tipos de gordura

\begin{tabular}{lccccc}
\hline Gordura & \multicolumn{5}{c}{ Machos aos 42 dias de idade } \\
& GP $(\mathrm{g})$ & CR $(\mathrm{g})$ & CA & GA $(\mathrm{g})$ & GA $(\%)$ \\
\hline Sebo Bovino & 2.595 & $3.770^{\mathrm{a}}$ & $2,03^{\mathrm{a}}$ & $54,18^{\mathrm{a}}$ & $2,00^{\mathrm{a}}$ \\
Óleo de Oliva & 2.580 & $3.649^{\mathrm{b}}$ & $1,98^{\mathrm{b}}$ & $54,82^{\mathrm{a}}$ & $2,07^{\mathrm{a}}$ \\
Óleo de Girassol & 2.606 & $3.490^{\mathrm{c}}$ & $1,87^{\mathrm{c}}$ & $45,46^{\mathrm{b}}$ & $1,70^{\mathrm{b}}$ \\
Óleo de linhaça & 2.592 & $3.476^{\mathrm{c}}$ & $1,88^{\mathrm{c}}$ & $46,94^{\mathrm{b}}$ & $1,75^{\mathrm{b}}$
\end{tabular}

Fonte: Crespo \& Esteve-Garcia (2001)

${ }^{a, b, c}$ Diferem estatisticamente na mesma coluna $(p<0,001)$

A não correção da energia metabolizável das gorduras pelos autores, adicionando 6 ou $10 \%$ a dieta, levam a uma distorção dos resultados de desempenho e acúmulo de gordura, provavelmente o óleo de girassol e o óleo de linhaça possuem mais energia, consumindo menos ração, melhorando a conversão alimentar e acumulando menos gordura na carcaça. Zollitsch et al. (1997) adicionaram 3,5\% de misturas comerciais de gorduras 
e obtiveram diferenças no desempenho e acúmulo de gordura abdominal, novamente sem considerar a energia contida em nas gorduras.

Gaiotto et al. (2000) mostraram que a adição de diferentes gorduras a $4 \%$ nas dietas afeta o desempenho de frangos de corte e o acúmulo de gordura devido ao diferencial de energia contida nas mesmas. Avaliar os tipos de gordura suplementadas as dietas de frangos de corte sem uma prévia determinação de energia, com interação dos conhecimentos específicos de digestão e absorção das gorduras, implicará em avaliações grosseiras e infundadas.

A finalidade deste trabalho foi determinar os valores de energia metabolizável aparente, energia metabolizável aparente corrigida para nitrogênio e digestibilidade aparente da gordura da dieta do óleo de soja, óleo ácido, óleo de vísceras de aves e suas misturas em diferentes proporções, na fase pré-inicial (0-7 dias de idade), inicial (8-21 dias), crescimento (22-35 dias) e final (36-42 dias) e sua influência no consumo de ração, ganho de peso, conversão alimentar, viabilidade e rendimento da carcaça de frangos de corte. 


\section{DETERMINAÇÃO DA ENERGIA METABOLIZÁVEL DE GORDURAS PARA FRANGOS DE CORTE}

\section{Resumo}

Foram realizados dois experimentos de metabolismo para a determinação da energia metabolizável aparente (EMA), energia metabolizável aparente corrigida para nitrogênio (EMAn) e digestibilidade aparente (DG) de diferentes gorduras para as fases pré-inicial, inicial, crescimento e final de frangos de corte. Nos experimentos de metabolismo os tratamentos consistiram de uma dieta referência e 5 dietas obtidas pela substituição de 10\%, peso por peso, da dieta referência pelas seguintes gorduras e suas misturas: óleo de soja (OS), óleo ácido (OA), óleo de vísceras de aves (OV), $50 \%$ de óleo de soja com $50 \%$ de óleo ácido (OS50/OA50), 50\% de óleo de soja com $50 \%$ de óleo de vísceras de aves (OS50/OV50) no primeiro experimento e as misturas: $75 \%$ de óleo de vísceras de aves com 25\% óleo soja (OV75/OS25), 75\% óleo de vísceras de aves com $25 \%$ óleo ácido (OV75/OA25), 50\% de óleo ácido com 50\% óleo de vísceras de aves (OA50/OV50), 75\% de óleo ácido com $25 \%$ óleo de vísceras de aves (OA75/OV25), $75 \%$ de óleo ácido com $25 \%$ de óleo de soja (OA75/OS25) no segundo experimento. A dieta referência era baseada em milho e farelo de soja, formuladas sem gordura suplementar. Em cada experimento foram realizados 4 ensaios correspondentes às fases de criação. Utilizaram-se 4 repetições por tratamento em delineamento inteiramente ao acaso. No primeiro experimento os valores de EMA, EMAn e $D G$ do $O A$ mostraram-se inferiores $(p<0,05)$ às das demais gorduras. A EMA, 
EMAn e a DG do OS50/OA50 e do OS50/OV50 não apresentaram diferenças ( $p>0,05)$ em relação ao OV e OS nas fases pré-inicial, inicial e crescimento, porém na fase final, essas misturas resultaram em energias metabolizáveis similares ao OV, menores que o OS e superiores ao OA. A DG das dietas com misturas de gordura não diferiu $(p>0,05)$ das dietas com OS e OV em todas as fases estudadas. No experimento 2 os valores de EMA, EMAn e DG para as misturas OA75/OV25, OA75/SO25, OA50/OV50 foram inferiores as demais gorduras nas fases pré-inicial, inicial e crescimento. A EMA, EMAn e a DG do OV75/OS25 foram superiores nas fases pré-inicial, inicial e crescimento. Em ambos os experimentos, os valores de EMA e EMAn das gorduras na fase pré-inicial foram inferiores quando comparados às demais fases.

\section{Summary}

Apparent metabolizable energy determination of fats to broiler chicken

Two metabolism trials were carried out to determine the apparent metabolizable energy (AME) and nitrogen-corrected apparent metabolizable energy (AMEn) of fats and their mixtures. In trial 1 the treatments consisted of a basal diet and 5 diets obtained by substituting, weight by weight, $10 \%$ of the basal diets with the fat sources: soybean oil (SO), acidulated soapstock (AS), poultry offal fat (PF), $50 \%$ soybean oil and $50 \%$ acidulated soapstock (SO50/AS50), $50 \%$ soybean oil and $50 \%$ poultry offal fat (SO50/PF50). In trial 2 , the following mixtures were fed: $75 \%$ poultry offal fat and $25 \%$ soybean oil (PF75/SO25), $75 \%$ poultry offal fat and $25 \%$ acidulated soapstock (PF75/AS25), $50 \%$ acidulated soapstock and $50 \%$ poultry offal fat (AS50/PF50), $75 \%$ acidulated soapstock and $25 \%$ poultry offal fat (AS75/PF25) and $75 \%$ acidulated soapstock and $25 \%$ soybean oil (AS75/SO25). The basal diet was based on corn and soybean meal, formulated with no added fat. Each treatment was replicated 4 times in a 
completely randomized design. In each trial there were 4 assays corresponding to the pre-starter (0-10 days), starter (11-21 days), grower (2235 days) and finisher (36-42 days) phases. In trial 1, AME and AMEn values for AS were lower $(p<0.05)$ than those for the other fats in all phases; this can be due to the elevated level of free fatty acids in AS. AME and AMEn of the mixture SO50/AS50, as well as the mixture (SO50/PF50), were not different from those of SO and PF in the pre-starter, starter and grower phases; however, in the finisher phase these mixtures resulted in metabolizable energy similar to PF ( $p>0.05)$, lower than SO and higher than AS $(p<0.05)$. In trial 2, AME and AMEn values were lower in the pre-starter, starter and grower phases for the mixtures AS75/PF25, AS75/SO25 and AS50/SO50 $(p<0.05)$. AME and AMEn were higher for PF75/SO25 in the pre-starter, starter and grower phases $(p<0.05)$. In both trials the metabolizable energy was lower for birds in the pre-starter phase than in the other phases.

\subsection{Introdução}

A energia metabolizável aparente (EMA) é uma das maneiras de dimensionar a parcela da energia ingerida (EI) a ser utilizada pelas aves. Formulações de rações que utilizam valores de energia errôneos sejam estes superestimados ou subestimados, refletem diretamente no desenvolvimento, na qualidade da carcaça e nos custos de produção das aves.

Inúmeros fatores levam a determinações equivocadas da EMA, principalmente aqueles que interferem na absorção das gorduras pelas aves, entre eles, a relação de ácidos graxos saturados e insaturados, a concentração de ácidos graxos livres, idade das aves, linhagem e níveis de suplementação das gorduras nas dietas.

A capacidade fisiológica das aves limita a absorção de gorduras na fase inicial de vida destas. Nos primeiros dias pós-nascimento os frangos de corte tem reduzida capacidade de absorção de gordura, como determina Carew et al. (1972) através de um experimento de digestibilidade da gordura 
da dieta com a suplementação de óleo de milho e sebo bovino. Os valores determinados da digestibilidade da gordura da dieta para ambas as gorduras foram inferiores na primeira semana (2 a 7 dias) em relação à segunda semana (8 a 15 dias) de vida dos frangos de corte machos. Em mais um ensaio de digestibilidade, agora apresentado por Wiseman \& Salvador (1989) detectaram-se menores valores de digestibilidade da gordura da dieta para o sebo bovino e para mistura de óleos vegetais adicionados à dieta aos 10 dias em relação aos 25 dias de vida.

A digestiblidade da gordura da dieta está intrinsecamente relacionada à utilização da energia ingerida na forma de gordura pelas aves. Segundo Wiseman \& Salvador (1989) o comportamento verificado da digestibilidade da gordura da dieta reflete nos valores determinados de EMA. Fatos descritos anteriormente mostram que a absorção de gordura na fase inicial de desenvolvimento das aves é prejudicada, e os fatores fisiológicos responsáveis para tal acontecimento são: a inferior capacidade de produção de lipase pancreática e de sais biliares pelos órgãos envolvidos na digestão. A inferior capacidade fisiológica de secreção de sais biliares por frangos de corte foi demonstrada por Noy \& Sklan (1995), pois se determinou que a secreção de sais biliares aumentou em 10 vezes no período de 4 a 21 dias de idade. Estes autores ainda quantificaram a secreção de lipase, tripsina e amilase pancreática e observaram um aumento de 20, 50 e 100 vezes, respectivamente, na secreção destas enzimas neste período. Em ensaio mais detalhado realizado por Noy \& Sklan (2000) demonstrou-se que a concentração de lipase era 5 vezes menor em relação a tripsina e a amilase no intestino delgado, aos 7 dias de idade.

A incapacidade de produção fisiológica dos sais biliares e lipase comprometem a absorção de gordura nas primeiras semanas de vida, indicando que é necessária uma maior atenção quando se suplementa altos níveis de gordura neste período de vida. Outros fatores podem reduzir a digestão e absorção de gorduras não apenas na fase inicial, mas também 
nas demais fases de vida das aves. O primeiro fator a ser discutido é a concentração de ácidos graxos livres (AGL) nas gorduras suplementadas nas dietas das aves.

Os processos de digestão e absorção das gorduras serão prejudicados com a presença dos ácidos graxos livres na dieta das aves. Algumas gorduras caracterizam-se pelos elevados níveis de ácidos graxos livres, como é o caso das gorduras hidrolisadas e dos resíduos do processo de neutralização dos óleos. A ação dos AGL na absorção das gorduras foi descrita por Young (1961), que utilizou uma mistura de óleo vegetal e gordura animal hidrolisada, totalizando $40 \%$ de AGL, comparada a uma mistura de gordura animal hidrolisada mais óleo ácido de soja, contendo 95\% de AGL e comparada ao óleo de milho como controle. A digestibilidade da gordura da dieta com óleo de milho foi de $91,4 \%$, enquanto que a da mistura que continha $40 \%$ de $A G L$ foi de $81,1 \%$, e que continha $95 \%$ de AGL foi de $69,6 \%$, na quarta semana de idade das aves. Corroborando com o autor anterior, Blanch et al. (1995) utilizaram em seu ensaio óleo de soja como controle, misturas de 1:1 de sebo bovino com óleo de soja ou com óleo ácido de soja e determinaram maiores valores de digestibilidade da gordura da dieta e energia metabolizável para o controle e a mistura sebo bovino e óleo de soja, ambos diferindo significativamente $(p<0,01)$ da mistura sebo e óleo ácido de soja. Uma hipótese plausível levantada em alguns trabalhos é que a presença do monoglicerídios no intestino delgado das aves estimularia a secreção de ácidos biliares responsáveis pela emulsificação das gorduras, elemento encontrado de em baixas concentrações em gorduras com níveis de AGL elevados.

Dentre os fatores que mais prejudicam a digestão e absorção de gorduras está à relação dos ácidos graxos saturados e insaturados das gorduras. Segundo Renner \& Rill (1961), os ácidos graxos saturados palmítico e esteárico tiveram uma absorção de $30 \%$ e $20 \%$, respectivamente, quando se utilizou uma gordura com $50 \%$ de ácidos graxos insaturados. Ao 
se elevar para $62 \%$ de ácidos graxos insaturados a absorção do palmítico e esteárico aumentou para $51 \%$ e $36 \%$ e com $76 \%$ de ácidos graxos insaturados a absorção foi de $84 \%$ e $78 \%$. Além destes autores, Young \& Garrett (1963) associaram que fontes ricas em ácido graxo palmítico $(P)$ e oléico (O) aumentaram em $10 \%$ a absorção de ácidos graxos saturados, quando se passou de uma relação $P: O$ de 1,34:1 para 0,8:1, demonstrando que há um mecanismo de facilitação da absorção de ácidos graxos saturados em presença de ácidos graxos insaturados. Um explicação adequada está no mecanismo de aborção dos ácidos graxos, pois os ácidos graxos insaturados formam as micelas mistas espontaneamente com os monoglicerídios e sais biliares, enquanto que os ácidos graxos saturados são encapsulados por estas micelas, assim a presença de elevadas concentrações de ácidos acidos graxos insaturados formará mais miscelas e carregará mais ácidos graxos saturados.

Além dos fatores intrínsecos a digestão e absorção de gorduras influenciar na determinação da digestibilidade da gordura da dieta e na EMA, fatores experimentais alteram a determinação da energia da gordura, entre estes, o nível de inclusão de gordura nas dietas, o tipo de dieta utilizada, ambiente, sexo, genética, sanidade, etc.

Toda discussão anterior mostra a enorme variação na absorção das gorduras e na determinação da energia metabolizável, tornando difícil a comparação dos valores determinados. Assim, a finalidade deste trabalho foi determinar os valores de energia metabolizável aparente, energia metabolizável aparente corrigida para nitrogênio e digestibilidade aparente da gordura da dieta do óleo de soja, óleo ácido, óleo de frango e suas misturas em diferentes proporções, nas fases pré-inicial (0-7 dias de idade), inicial (8-21 dias), crescimento (22-35 dias) e final (36-42 dias) de frangos de corte. 


\subsection{Material e Métodos}

As determinações da energia metabolizável aparente, energia metabolizável aparente corrigida para nitrogênio, digestibilidade aparente da gordura das rações foram realizadas em dois experimentos no Departamento de Zootecnia da Escola Superior de Agricultura "Luiz de Queiroz", USP Piracicaba. Em ambos os experimentos foram utilizados 600 pintos machos da linhagem AgRoss, divididos em 4 ensaios correspondentes as fases de criação: pré-inicial (0 - 10 dias), inicial (11 - 21 dias), crescimento (22 -35 dias) e final (36 - 42 dias de idade).

As aves foram inicialmente alojados em 24 gaiolas metabólicas Petersime de $1 \mathrm{~m}$ de comprimento, por 0,68 $\mathrm{m}$ de largura e 0,20 $\mathrm{m}$ de altura, com aquecimento para as primeiras semanas de criação. Nestas gaiolas as aves foram criadas até 21 dias de idade, distribuídas em 6 tratamentos e 4 repetições em delineamento inteiramente casualizado. Cada parcela continha 10 aves por gaiola para fase pré-inicial e 8 aves por gaiola para fase inicial. Após os 21 dias de idade, as aves foram criadas em gaiolas Petersime de 0,70 $\mathrm{m}$ de comprimento por 0,66 $\mathrm{m}$ de largura e 0,34 $\mathrm{m}$ de altura, com 4 aves por gaiolas na fase de crescimento e 3 aves por gaiola na fase final. Na fase pré-inicial as aves foram alojadas diretamente nas gaiolas metabólicas e as aves restantes foram alojadas no galpão experimental, onde receberam ração (dieta referência) e água à vontade. Para cada ensaio as aves das gaiolas eram substituídas pelas aves do galpão, selecionadas a partir do peso médio do lote do galpão com uma variação de $\pm 5 \%$. As aves utilizadas nos ensaios de metabolismo não eram reutilizadas em ensaios subseqüentes.

Para cada fase de criação, forneceu-se a dieta referência substituída em $10 \%$, peso por peso, pela gordura a ser determinada energia metabolizável. As rações foram formuladas a base de milho e farelo de soja a partir dos níveis de nutrientes empregados na indústria avícola e de Rostagno et al. (2000) (Tabela 1). 
Em cada ensaio, foram feitos três dias de adaptação às gaiolas, exceto para a fase pré-inicial, 3 dias de adaptação às dietas experimentais e 4 dias de coleta total de excretas. Para a determinação exata do início e fim do período de coleta de excretas, foi utilizado $1 \%$ de óxido de ferro como indicador nas rações. Na fase pré-inicial, a coleta de excretas iniciou-se no $4^{\circ}$ dia de criação, na fase inicial no $15^{\circ}$ dia, na fase crescimento no $27^{\circ}$ dia e na fase final no $39^{\circ}$ dia.

Depois de coletadas, as excretas foram acondicionadas em baldes plásticos e congeladas a $-18^{\circ} \mathrm{C}$. Ao final dos ensaios, as excretas foram descongeladas, homogeneizadas e submetidas à pré-secagem. O processo de pré-secagem foi realizado em estufas de circulação forçada de ar a $65^{\circ} \mathrm{C}$ por 72 horas. As amostras das dietas experimentais e das excretas foram encaminhadas ao Laboratório de Bromatologia do Departamento de Zootecnia para determinação da energia bruta em Bomba Calorimétrica (modelo Parr 1261). As análises de umidade, proteína bruta e extrato etéreo foram realizadas em laboratório (CBOneida Ltda $M E$ ), seguindo a metodologia proposta por Silva (1990). Além disso, foram determinados para cada parcela, o consumo de ração e a quantidade de excretas produzidas. Os resultados obtidos nas análises, juntamente com consumo de ração e produção de excretas, foram utilizados no cálculo da energia metabolizável aparente e energia metabolizável aparente corrigida para nitrogênio, segundo a metodologia de Matterson et al. (1965). A digestibilidade aparente da gordura das dietas foi obtida segundo Carew et al. (1972). 
Equação de determinação da EMAn segundo Matterson et al. (1965):

EMAn ingerida $=\underline{\text { EMAn referência }+(\text { EMAn teste }- \text { EMAn referência })}$

(\% substituição/100)

Onde:

-EMAn - energia metabolizável aparente corrigida pelo balanço de nitrogênio calculada (kcal/kg);

-Ingerida - ingrediente testado;

-Referência - dieta referência;

-Teste - dieta referência + ingrediente teste;

-\% substituição - nível de substituição da dieta referência pelo ingrediente testado.

Equação de determinação da DG da dieta segundo Carew et al. (1972):

$D G=\underline{\text { Gordura ingerida }- \text { Gordura excretada }}$ Gordura ingerida

Onde:

DG - digestibilidade da gordura da dieta (\%);

Gordura ingerida - gordura ingerida na dieta teste;

Gordura excretada - gordura excretada pela dieta teste. 
Tabela 1. Composição das dietas basais

\begin{tabular}{|c|c|c|c|c|}
\hline Ingredientes, \% & Pré-Inicial| $^{4}$ & Inicial $^{4}$ & Crescimento $^{5}$ & Final \\
\hline Milho & 59,25 & 64,57 & 67,32 & 70,38 \\
\hline Farelo de soja & 36,60 & 31,26 & 28,72 & 26,01 \\
\hline Fosfato bicálcico & 1,88 & 1,91 & 1,63 & 1,43 \\
\hline Calcário calcítico & 1,03 & 1,05 & 1,25 & 1,15 \\
\hline Sal & 0,50 & 0,50 & 0,50 & 0,50 \\
\hline Lisina. $\mathrm{HCl}$ & 0,17 & 0,15 & 0,10 & 0,08 \\
\hline DL- Metionina & 0,20 & 0,17 & 0,11 & 0,10 \\
\hline Suplemento vitamínico & $0,30^{1}$ & $0,30^{1}$ & $0,30^{2}$ & $0,30^{2}$ \\
\hline Suplemento mineral ${ }^{3}$ & 0,05 & 0,05 & 0,05 & 0,05 \\
\hline Nutrientes & \multicolumn{4}{|c|}{ Níveis calculados } \\
\hline EM (kcal/kg) & 2.843 & 2.900 & 2.930 & 2.970 \\
\hline PB (\%) & 22,0 & 20,0 & 19,0 & 18,0 \\
\hline Metionina (\%) & 0,53 & 0,49 & 0,41 & 0,39 \\
\hline Met. + cis. $(\%)$ & 0,92 & 0,85 & 0,76 & 0,73 \\
\hline Lisina (\%) & 1,30 & 1,15 & 1,05 & 0,96 \\
\hline Fósforo disp. (\%) & 0,46 & 0,46 & 0,41 & 0,37 \\
\hline Cálcio (\%) & 1,00 & 1,00 & 1,00 & 0,90 \\
\hline
\end{tabular}

1-Concentração por kg de ração: Ácido fólico, $1 \mathrm{mg}$; ácido pantotênico, $15 \mathrm{mg}$; antioxidante, 22,5 mg; biotina, $60 \mathrm{mg}$; colina, $400 \mathrm{mg}$; niacina, $40 \mathrm{mg}$; selênio, $0,3 \mathrm{mg}$; vitamina $A, 8.000 \mathrm{Ul}$; vitamina $B_{1}, 1,8$ mg; vitamina $B_{12}, 12$ mcg; vitamina $B_{2}, 6 \mathrm{mg}$; vitamina $B_{6}, 2 ., 8 \mathrm{mg}$; vitamina $D_{3}, 2.000$ Ul; vitamina $E, 15$ $\mathrm{UI}$; vitamina $\mathrm{K}, 1,8 \mathrm{mg}$.

2-Concentração por $\mathrm{kg}$ de ração: Ácido fólico, $0,7 \mathrm{mg}$; ácido pantotênico, 13mg; antioxidante, 15g; colina, $300 \mathrm{mg}$; niacina, 3,5mg; selênio, $0,3 \mathrm{mg}$; vitamina $A, 7.000 \mathrm{Ul}$; vitamina $B_{1}, 1,6 \mathrm{mg}$; vitamina $B_{12}$, 10 mcg; vitamina $B_{2}, 5 \mathrm{mg}$; vitamina $B_{6}, 2,6 \mathrm{mg}$; vitamina $D_{3}, 1.500 \mathrm{UI}$; vitamina $\mathrm{E}, 12 \mathrm{UI}$; vitamina $\mathrm{K}, 1,5$ mg.

3-Concentração por kg de ração: Manganês, 75 mg; cobre, 8 mg; zinco, 50 mg; ferro, 50 mg; iodo, 0,75 $\mathrm{mg}$

4- Olaquindox, $40 \mathrm{mg} / \mathrm{kg}$; Avilamicina, $5 \mathrm{mg} / \mathrm{kg}$; Nicarbazina, $110 \mathrm{mg} / \mathrm{kg}$;

5- Olaquindox, 40 mg/kg; Avilamicina, 5 mg/kg; Salinomicina 12\%, 66 mg/kg; Ácido 3-nitro, 35 mg/kg.

As gorduras utilizadas nos experimentos foram o óleo de soja, o óleo ácido e a óleo de vísceras, caracterizados qualitativamente nas Tabelas 2 e 3. 
Tabela 2. Análise de qualidade das gorduras

\begin{tabular}{lccccccc}
\hline Análises & Unidade & \multicolumn{2}{c}{ Óleo de soja } & \multicolumn{2}{c}{ Óleo ácido } & \multicolumn{2}{c}{ Óleo vísceras } \\
& & Exp. 1 & Exp. 2 & Exp. 1 & Exp. 2 & Exp. 1 & Exp. 2 \\
\hline Umidade & $\%$ & 0,12 & 0,28 & 3,55 & 2,31 & 0,14 & 2,42 \\
Ext.Etéreo & $\%$ & 99,15 & 99,10 & 95,46 & 94,94 & 97,49 & 97,35 \\
In. Peróxido & $\mathrm{mEq} / \mathrm{kg}$ & 0 & 0 & 0 & 0 & 0 & 0 \\
In. Acidez & $\mathrm{gNaOH} / \mathrm{g}$ & 0,43 & 5,4 & 106,2 & 80,58 & 2,95 & 12,19 \\
Ener. Bruta & $\mathrm{kcal} / \mathrm{kg}$ & 9.354 & 9.402 & 8.922 & 9.324 & 9.378 & 9.333
\end{tabular}

A qualidade das gorduras utilizadas nos experimentos está dentro dos padrões de qualidade esperados, destacando-se o elevado índice de acidez e baixa energia bruta do óleo ácido no experimento 2 .

Tabela 3. Perfil de ácidos graxos das gorduras, em \% ácidos graxos totais

\begin{tabular}{lcccccc}
\hline \multirow{2}{*}{ Ácidos graxos } & \multicolumn{5}{c}{ \% ácidos graxos totais } \\
& \multicolumn{2}{c}{ Óleo de soja } & \multicolumn{2}{c}{ Óleo ácido } & \multicolumn{2}{c}{ Óleo de vísceras } \\
& Exp. 1 & Exp. 2 & Exp. 1 & Exp. 2 & Exp.1 & Exp. 2 \\
\hline 16:0 (palmítico) & 11,39 & 18,35 & 15,10 & 28,06 & 23,04 & 32,15 \\
18:0 (esteárico) & 3,55 & 2,99 & 3,80 & 3,10 & 5,22 & 4,96 \\
16:1 (palmitoléico) & - & - & - & - & 9,12 & 10,58 \\
18:1 $\omega 9$ (oléico) & 23,50 & 22,17 & 22,00 & 26,27 & 45,16 & 37,01 \\
18:2 $\omega 6$ (linoléico) & 53,60 & 49,71 & 52,09 & 37,02 & 15,77 & 13,33 \\
18:3 $\omega 3$ (linolênico) & 6,97 & 5,63 & 5,14 & 2,84 & 0,52 & 0,45 \\
Saturados & 15,63 & 21,34 & 20,00 & 33,15 & 28,93 & 38,41 \\
Insaturados & 84,07 & 77,88 & 79,23 & 66,13 & 71,06 & 61,37 \\
Polinsaturados & 60,57 & 55,34 & 57,23 & 39,86 & 16,29 & 13,78 \\
\hline
\end{tabular}


O perfil dos ácidos graxos do óleo de soja e óleo de vísceras de aves varia pouco entre os experimentos, no entanto o nível do ácido graxo linoléico do óleo ácido foi inferior e o palmítico superior no experimento 2.

Os tratamentos utilizados nos experimentos 1 e 2 são mostrados na Tabela 4.

Tabela 4. Distribuição dos tratamentos

\begin{tabular}{|c|c|c|c|c|}
\hline \multirow[b]{2}{*}{ Tratamentos } & \multirow[b]{2}{*}{ Sigla } & \multicolumn{3}{|c|}{$\%$ na mistura } \\
\hline & & $\begin{array}{c}\text { Óleo de } \\
\text { soja }\end{array}$ & $\begin{array}{l}\text { Óleo } \\
\text { ácido }\end{array}$ & $\begin{array}{c}\text { Óleo } \\
\text { vísceras }\end{array}$ \\
\hline Óleo ácido ${ }^{1}$ & $\mathrm{OA}$ & - & 100 & - \\
\hline Óleo de vísceras de aves ${ }^{1}$ & OV & - & - & 100 \\
\hline Óleo soja ${ }^{1}$ & OS & 100 & - & - \\
\hline Óleo soja 50/ óleo ácido $50^{1}$ & OS50/OA50 & 50 & 50 & - \\
\hline Óleo soja 50 / ól. vísceras $50^{1}$ & OS50/OV50 & 50 & - & 50 \\
\hline Óı. vísceras $75 /$ óleo soja $25^{2}$ & OV75/OS25 & 25 & - & 75 \\
\hline Óı. vísceras 75 / óleo ácido $25^{2}$ & OV75/OA25 & - & 25 & 75 \\
\hline Óleo ácido $50 /$ ól. vísceras $50^{2}$ & OA50/OV50 & - & 50 & 50 \\
\hline Óleo ácido $75 /$ ól. vísceras $25^{2}$ & OA75/OV25 & - & 75 & 25 \\
\hline Óleo ácido $75 /$ óleo soja $25^{2}$ & OA75/OS25 & 25 & 75 & - \\
\hline
\end{tabular}

A análide de variância foi realizada pelo procedimento PROC GLM (Genral Linear Models) do programa Statistical Analysis System, 1989. A comparação de médias foram realizadas pelo teste de Tukey $(p<0,05)$. 


\subsection{Resultados e Discussão}

Os valores determinados de energia metabolizável aparente (EMA) das gorduras encontram-se na Tabela 5 e os valores de energia metabolizável corrigida para nitrogênio (EMAn) encontram-se na Tabela 6 para as fases pré-inicial, inicial, crescimento e final.

No experimento 1 os valores de EMA e EMAn do óleo ácido mostraram-se inferiores $(p<0,05)$ aos das demais gorduras. Isto pode ser devido a sua composição apresentar elevados níveis de ácidos graxos livres. A presença de ácidos graxos livres nas gorduras é mensurada pelo índice de acidez, que no caso do óleo ácido mostrou-se elevado (Tabela 2).

A digestibilidade aparente da gordura das rações das fases inicial, crescimento e final contendo o óleo ácido foram inferiores $(p<0,05) \mathrm{em}$ relação a das demais gorduras (Tabela 7). A ausência de triglicerídios reduz a ativação da secreção de bile, afetando a formação de micelas no intestino delgado, reduzindo a digestibilidade da gordura e a disponibilidade da energia para as aves (Wiseman \& Salvador ,1991; Vila \& Garcia, 1996). 
Tabela 5. Valores de energia metabolizável aparente (EMA) das gorduras na fase pré-inicial, inicial, crescimento e final de frangos de corte nos experimentos 1 e 2

\begin{tabular}{lccccc}
\hline \multirow{2}{*}{ Tratamentos } & Exp. & Pré-inicial & Inicial & Crescimento & Final \\
\hline OA & 1 & $6.715^{\mathrm{b}}$ & $6.973^{\mathrm{b}}$ & $7.741^{\mathrm{b}}$ & $7.885^{\mathrm{C}}$ \\
OV & 1 & $7.950^{\mathrm{a}}$ & $8.506^{\mathrm{a}}$ & $8.910^{\mathrm{a}}$ & $9.044^{\mathrm{ab}}$ \\
OS & 1 & $8.200^{\mathrm{a}}$ & $9.028^{\mathrm{a}}$ & $9.088^{\mathrm{a}}$ & $9.133^{\mathrm{a}}$ \\
OS50/OA50 & 1 & $8.094^{\mathrm{a}}$ & $8.687^{\mathrm{a}}$ & $8.793^{\mathrm{a}}$ & $8.897^{\mathrm{ab}}$ \\
OS50/OV50 & 1 & $8.126^{\mathrm{a}}$ & $8.452^{\mathrm{a}}$ & $8.694^{\mathrm{a}}$ & $8.730^{\mathrm{b}}$ \\
OV75/OS25 & 2 & $8.213^{\mathrm{A}}$ & $8.181^{\mathrm{A}}$ & $8.552^{\mathrm{B}}$ & $8.610^{\mathrm{B}}$ \\
OV75/OA25 & 2 & $7.808^{\mathrm{B}}$ & $8.087^{\mathrm{A}}$ & $8.780^{\mathrm{A}}$ & $8.913^{\mathrm{A}}$ \\
OA50/OV50 & 2 & $7.700^{\mathrm{BC}}$ & $8.086^{\mathrm{A}}$ & $8.125^{\mathrm{C}}$ & $9.012^{\mathrm{A}}$ \\
OA75/OV25 & 2 & $7.422^{\mathrm{D}}$ & $7.565^{\mathrm{B}}$ & $7.925^{\mathrm{D}}$ & $8.147^{\mathrm{C}}$ \\
OA75/OS25 & 2 & $7.521^{\mathrm{CD}}$ & $7.797^{\mathrm{B}}$ & $8.145^{\mathrm{C}}$ & $8.373^{\mathrm{BC}}$ \\
CV (\%) & 1 & 6,90 & 3,60 & 2,54 & 2,00 \\
CV (\%) & 2 & 4,40 & 2,88 & $1,95^{\circ}$ & 1,43 \\
\hline a,b,c Diferem estatisticamente na mesma coluna $(\mathrm{p}<0,05)$ & & \\
A,B,C,D Diferem estatisticamente na mesma coluna $(\mathrm{p}<0,05)$ & & \\
& & & &
\end{tabular}


Tabela 6. Valores de energia metabolizável aparente corrigida para nitrogênio (EMAn) das gorduras para frangos de corte

\begin{tabular}{lccccc}
\hline \multirow{2}{*}{ Tratamentos } & Exp. & Pré-inicial & Inicial & Crescimento & Final \\
\hline OA & 1 & $6620^{\mathrm{b}}$ & $6768^{\mathrm{b}}$ & $7610^{\mathrm{b}}$ & $7793^{\mathrm{C}}$ \\
OV & 1 & $7815^{\mathrm{ab}}$ & $8338^{\mathrm{a}}$ & $8743^{\mathrm{a}}$ & $8991^{\mathrm{ab}}$ \\
OS & 1 & $8038^{\mathrm{a}}$ & $8861^{\mathrm{a}}$ & $8866^{\mathrm{a}}$ & $9094^{\mathrm{a}}$ \\
OS50/OA50 & 1 & $7993^{\mathrm{a}}$ & $8472^{\mathrm{a}}$ & $8480^{\mathrm{a}}$ & $8700^{\mathrm{b}}$ \\
OS50/OV50 & 1 & $7860^{\mathrm{a}}$ & $8298^{\mathrm{a}}$ & $8479^{\mathrm{a}}$ & $8640^{\mathrm{b}}$ \\
OV75/OS25 & 2 & $7844^{\mathrm{A}}$ & $8136^{\mathrm{A}}$ & $8347^{\mathrm{A}}$ & $8462^{\mathrm{C}}$ \\
OV75/OA25 & 2 & $7498^{\mathrm{B}}$ & $7984^{\mathrm{B}}$ & $8440^{\mathrm{A}}$ & $8808^{\mathrm{A}}$ \\
OA50/OV50 & 2 & $7233^{\mathrm{C}}$ & $7845^{\mathrm{C}}$ & $7915^{\mathrm{B}}$ & $8687^{\mathrm{B}}$ \\
OA75/OV25 & 2 & $7039^{\mathrm{D}}$ & $7398^{\mathrm{E}}$ & $7835^{\mathrm{B}}$ & $8065^{\mathrm{E}}$ \\
OA75/OS25 & 2 & $7280^{\mathrm{C}}$ & $7666^{\mathrm{D}}$ & $7922^{\mathrm{B}}$ & $8287^{\mathrm{D}}$ \\
CV (\%) & 1 & $7,17^{\mathrm{C}}$ & 3,60 & 2,48 & 1,90 \\
CV (\%) & 2 & 4,13 & $2,37^{\circ}$ & 1,11 & 1,01 \\
\hline a,b,c Diferem estatisticamente na mesma coluna (p<0,05) & & \\
A,B,C,D,E Diferem estatisticamente na mesma coluna (p<0,05) & &
\end{tabular}

Os valores de EMA e EMAn do óleo de soja e do óleo de vísceras de aves foram superiores $(p<0,05)$ aos do óleo ácido em todas as fases de criação, pois as suas composições em triglicerídios refletem numa digestibilidade aparente da gordura das dietas superior $(p<0,05)$ em relação ao óleo ácido (Tabela 7) em três das quatro fases testadas.

O valor da EMAn do óleo de soja de $8.861 \mathrm{kcal} / \mathrm{kg}$, determinado no experimento 1, foi inferior ao valor determinado por Andreotti et al. (2000) aos 22 dias de idade das aves $(9.201 \mathrm{kcal} / \mathrm{kg})$ e superior ao valor determinado por Cardoso et al. (2000) de $8.331 \mathrm{Kcal} / \mathrm{kg}$. Isto mostra a dificuldade de adoção de um determinado valor condizente com a gordura utilizada nas dietas. A variação dos valores pode ser atrelada aos erros 
intrínsicos na metodologia de determinação da energia metabolizável aparente e a falta de uma melhor caracterização das gorduras utilizadas.

Tabela 7. Valores de digestibilidade aparente da gordura das rações na fase pré-inicial, inicial, crescimento e final de frangos de corte

\begin{tabular}{lccccc}
\hline \multirow{2}{*}{ Tratamentos } & Exp. & \multicolumn{4}{c}{ Digestibilidade aparente (\%) } \\
& & Pré-inicial & Inicial & Crescimento & Final \\
\hline OA & 1 & $77,0^{\mathrm{a}}$ & $78,6^{\mathrm{b}}$ & $88,3^{\mathrm{b}}$ & $85,3^{\mathrm{b}}$ \\
OV & 1 & $83,0^{\mathrm{a}}$ & $86,8^{\mathrm{a}}$ & $90,2^{\mathrm{ab}}$ & $91,8^{\mathrm{a}}$ \\
OS & 1 & $82,6^{\mathrm{a}}$ & $90,3^{\mathrm{a}}$ & $93,7^{\mathrm{a}}$ & $91,8^{\mathrm{a}}$ \\
OS50/OA50 & 1 & $84,2^{\mathrm{a}}$ & $86,1^{\mathrm{a}}$ & $90,9^{\mathrm{ab}}$ & $91,5^{\mathrm{a}}$ \\
OS50/OV50 & 1 & $83,2^{\mathrm{a}}$ & $87,3^{\mathrm{a}}$ & $93,6^{\mathrm{a}}$ & $92,8^{\mathrm{a}}$ \\
OV75/OS25 & 2 & $91,8^{\mathrm{A}}$ & $89,3^{\mathrm{A}}$ & $93,0^{\mathrm{AB}}$ & $89,3^{\mathrm{A}}$ \\
OV75/OA25 & 2 & $91,2^{\mathrm{AB}}$ & $85,7^{\mathrm{B}}$ & $93,6^{\mathrm{A}}$ & $89,8^{\mathrm{A}}$ \\
OA50/OV50 & 2 & $90,0^{\mathrm{AB}}$ & $86,3^{\mathrm{B}}$ & $92,2^{\mathrm{AB}}$ & $89,4^{\mathrm{A}}$ \\
OA75/OV25 & 2 & $88,2^{\mathrm{B}}$ & $85,5^{\mathrm{B}}$ & $88,0^{\mathrm{C}}$ & $81,2^{\mathrm{B}}$ \\
OA75/OS25 & 2 & $90,2^{\mathrm{AB}}$ & $84,3^{\mathrm{B}}$ & $89,4^{\mathrm{BC}}$ & $85,5^{\mathrm{AB}}$ \\
CV (\%) & 1 & 4,66 & 2,51 & 1,90 & 1,71 \\
CV (\%) & 2 & 2,87 & 1,83 & 1,79 & 1,36 \\
\hline a,b Diferem estatisticamente na mesma coluna (p<0,05) & & \\
A,B,C Diferem estatisticamente na mesma coluna (p<0,05) & &
\end{tabular}

As misturas entre gorduras, neste trabalho, tiveram a finalidade de suprir a ausência de ácidos graxos livres, neste caso, do óleo ácido, com os triglicerídios contidos no óleo de soja e melhorar a absorção de ácidos graxos saturados do óleo de vísceras de aves, mediante a presença de ácidos graxos insaturados do óleo de soja. Renner \& Hill (1961) constataram que os ácidos graxos saturados, principalmente palmítico e esteárico, tiveram sua absorção elevada com maiores níveis de ácidos graxos insaturados nas gorduras. Da mesma forma, Sibbald et al. (1961) misturaram 50\% de óleo de 
soja (insaturado) com $50 \%$ de sebo bovino (saturado) e observaram o aumento da digestibilidade do sebo.

No experimento 1 a EMA e a EMAn das misturas de óleo de soja e óleo ácido ou óleo de soja e óleo de vísceras de aves não apresentaram diferenças estatatísticas significativas $(p>0,05)$ em relação ao óleo de vísceras de aves e óleo de soja nas fases de pré-inicial, inicial e crescimento. Para a fase final as misturas apresentaram valores de energia metabolizável intermediários, não diferindo do óleo de vísceras de aves $(p>0,05)$, mas sendo inferiores $(p<0,05)$ ao óleo de soja e superiores $(p<0,05)$ ao óleo ácido (Tabelas 5 e 6). A digestibilidade aparente das rações contendo misturas de gordura não difere estatisticamente $(p>0,05)$ da ração contendo óleo de soja e óleo de vísceras de aves em todas as fases estudadas, mostrando que a presença de triglicerídios do óleo de soja supre a deficiência do óleo ácido e a mistura óleo de soja e óleo de vísceras de aves mantém-se com a digestibilidade equivalente ao óleo de soja e o óleo de vísceras de aves.

No experimento 2 os valores de EMA são inferiores para os tratamentos que contém $75 \%$ de óleo ácido (OA75/OV25 e OA75/OS25) em todas as fases de criação. Os valores de EMAn são inferiores para os tratamentos que contêm 50\% e 75\% de óleo ácido (OA75/OV25, OA75/OS25 e OA50/OV50), nas fases pré-inicial, inicial e crescimento (Tabelas 5 e 6). Na fase final, as misturas OA75/OV25, OA75/SO25 e OV75/OS25 resultaram em valores inferiores $(p<0,05)$. Os maiores valores de EMA e EMAn foram determinados na misturas que continham $75 \%$ de óleo de vísceras de aves, nas fases pré-inicial, inicial e crescimento. A exceção caracterizou-se na fase final de criação, pois a mistura com $50 \%$ de óleo ácido com $50 \%$ de óleo de vísceras de aves superou os valores de EMA da misturas com $75 \%$ de óleo de vísceras de aves e na EMAn superou apenas o valor da mistura óleo de soja $25 \%$ com $75 \%$ de óleo de vísceras de aves $(p<0,05)$. A digestibilidade aparente da gordura das dietas contendo misturas de gordura com $50 \%$ e $75 \%$ de óleo de vísceras de aves (OV75/OS25, OV75/OA25 e OA50/OV50) 
foram superiores para as fases pré-inicial, crescimento e final. A exceção caracterizou-se na fase inicial, pois a digestibilidade da mistura $75 \%$ de óleo de vísceras de aves com $25 \%$ de óleo de soja superou todos as demais misturas $(p<0,05)$. As misturas com $75 \%$ de óleo ácido (OA75/OV25 e OA75/OS25) tiveram DG inferiores as demais nas fases pré-inicial, crescimento e final. Os resultados obtidos por Wiseman \& Salvador (1991) mostraram uma redução mais acentuda da DG com níveis de AGL acima $75 \%$ nas gorduras, como nos tratamentos com OA75/OV25 e OA75/OS25.

Há uma coerência entre valores determinados de EMA e EMAn com os valores de digestibilidade aparente da gordura da ração apresentados no dois ensaios, pois à medida que decresce a energia, há redução na digestibilidade nas diferentes fases de criação, assim como mostram Blanch et al. (1995).

Em ambos os experimentos os valores de EMA e EMAn na fase préinicial foram inferiores, quando comparados com os valores das demais fases. A reduzida capacidade de absorção de gordura neste período de desenvolvimento das aves foi conseqüência da menor produção de lipase pancreática e sais biliares pelos órgãos envolvidos na digestão. Noy \& Sklan (1995) determinaram que secreção de sais biliares em frangos de corte aumentou em 10 vezes no período de 4 a 21 dias de idade. Os mesmos autores ainda quantificaram a secreção de lipase, tripsina e amilase pancreática e observaram um aumento de 20, 50 e 100 vezes, respectivamente, na secreção destas enzimas neste período. Noy \& Sklan (2000) ainda demonstraram que a concentração de lipase era 5 vezes menor em relação a tripsina e a amilase no intestino delgado, aos 7 dias de idade.

Os valores de energia metabolizável aparente das gorduras determinados em diferentes fases permite ajustar de forma adequada às energias das formulações de rações evitando o desequilíbrio energético com outros nutrientes, principalmente a proteína. 


\subsection{Conclusões}

Os valores de energia metabolizável aparente e energia metabolizável aparente corrigida para nitrogênio determinados podem ser utilizados como referência nas formulações de rações, com a vantagem de ajustar os valores de energia metabolizável para as fases pré-inicial, inicial, crescimento e final de frangos de corte. 


\section{AVALIAÇÃO DO DESEMPENHO E RENDIMENTOS DA CARCAÇA DE FRANGOS DE CORTE ALIMENTADOS COM DIETAS FORMULADAS COM DIFERENTES GORDURAS}

\section{Resumo}

Neste experimento utilizaram-se as mesmas fases de criação e os valores de EMAn determinados nos experimentos anteriores. Os tratamentos selecionados foram óleo ácido (OA), óleo de soja (OS), óleo de vísceras de aves (OV), $75 \%$ de óleo ácido com $25 \%$ de óleo de soja (75OA/25OS), $50 \%$ de óleo ácido com $50 \%$ de óleo de soja (500A/50OS) e 50\% óleo de vísceras de aves com $50 \%$ de óleo de soja (50OV/50OS), com 6 repetições e 40 aves por parcela, alimentadas com rações isoprotéicas e isoenergéticas a base de milho e farelo de soja. Foram determinados o desempenho, rendimento e peso da carcaça e suas partes, resultando no inferior desempenho do OS em relação aos demais tratamentos. Não houve diferenças significativas entre os tratamentos no acúmulo de gordura, peso do fígado e rendimentos da carcaça e das partes. O OA resultou em desempenho semelhante ao das demais gorduras, evidenciando que o uso de valores de energia metabolizável adequados na formulação das dietas permite que diferentes gorduras ou suas misturas possam ser fornecidas sem perda de desempenho. Além disso, em virtude do ganho energético resultante da mistura $50 \%$ OA com $50 \%$ OS, a quantidade de gordura suplementada pode ser reduzida obtendo-se o mesmo desempenho das aves. Mortalidade ocorrida na última semana de criação concorreu para a 
menor viabilidade do tratamento $\mathrm{OA}(\mathrm{P}<0,05)$. Os pesos absolutos da carcaça, peito, coxa e sobrecoxa foram inferiores para o OS, assim como o desempenho das aves. Não houve diferença significativa $(P>0,05)$ para os rendimentos relativos ao peso de abate da carcaça, gordura abdominal, fígado, peito, coxa e sobrecoxa de frangos de corte.

\section{Summary}

Evaluation of performance and carcass yield from broilers fed diets containing types of fats

In a performance trial diets were formulated using the AMEn of fats previously determined for pre-starter, starter, grower and finisher phases. Selected treatments were acidulated soapstock (AS), soybean oil (SO), poultry offal fat (PF), $75 \%$ acidulated soapstock and $25 \%$ soybean oil (AS75/SO25), $50 \%$ acidulated soapstock and $50 \%$ soybean oil (AS50/SO50) and $50 \%$ poultry offal fat and $50 \%$ soybean oil (PF50/SO50) with 6 replicates and 40 mbirds per pen. Diets were isoproteic and isoenergetic.

Growth performance and carcass and parts yield were determined. Treatments did not result in significant differences $(p>0.05)$, except for SO which was inferior to the other treatments. There were no differences among treatments in carcass and parts yield.

\subsection{Introdução}

A avaliação da qualidade da carcaça de frangos de corte é uma forma de ratificar o efeito dos resultados obtidos em experimentos de nutrição. Os ganhos significativos de desempenho não significam melhores rendimentos de carcaças e das suas partes. O desequilíbrio nutricional dos ingredientes protéicos e energéticos resulta em maior acúmulo de gordura e perda de rendimento da carcaça. 
Inúmeros fatores, apesar de serem descritos isoladamente, se interrelacionam com o rendimento de carcaça e o acúmulo de gordura na carcaça de frangos, tais como sexo, idade, genética e nutrição.

A nutrição exerce influência direta no rendimento de carcaça, partes e na gordura acumulada nas aves, através da relação energia-proteína das dietas, os níveis de gordura suplementados nas dietas e o pelo efeito específico do tipo de gordura suplementado nas dietas.

As características da carcaça relacionadas ao acúmulo de gordura estão diretamente relacionadas à relação energia-proteína das dietas fornecidas aos frangos de corte. Dutra Jr. et al. (1991) determinaram o desempenho e avaliaram o acúmulo de gordura na carcaça de frangos de corte alimentados com diferentes relações energia-proteína, através da suplementação de vários níveis de gordura (Tabelas 1 e 2).

Tabela 1. Consumo de ração (CR), ganho de peso (GP) e conversão alimentar (CA) de frangos de corte alimentados com diferentes relações energia-proteína pela suplementação de óleo de vísceras de aves (OV) de 1 a 49 dias de idade

\begin{tabular}{ccccc}
\hline OV (\%) & Energia-proteína & CR $(\mathrm{g})$ & GP $(\mathrm{g})$ & CA \\
\hline 0 & 158,3 & $3816^{\mathrm{a}}$ & $1782^{\mathrm{c}}$ & $2,15^{\mathrm{a}}$ \\
2 & 166,3 & $3840^{\mathrm{a}}$ & $1833^{\mathrm{bc}}$ & $2,10^{\mathrm{a}}$ \\
4 & 171,4 & $3791^{\mathrm{a}}$ & $1857^{\mathrm{b}}$ & $2,04^{\mathrm{ab}}$ \\
6 & 176,4 & $3915^{\mathrm{a}}$ & $1896^{\mathrm{ab}}$ & $2,07^{\mathrm{ab}}$ \\
8 & 181,2 & $3784^{\mathrm{a}}$ & $1940^{\mathrm{a}}$ & $1,96^{\mathrm{b}}$
\end{tabular}

Fonte: Dutra Jr. et al. (1991)

${ }^{a, b, c}$ Diferem estatisticamente na mesma coluna $(p<0,01)$

O estreitamento da relação energia-proteína resultou em um inferior ganho de peso, acompanhado pela piora da conversão alimentar. A dieta com pior 
conversão alimentar não continha suplementação de gordura. À medida que a suplementação aumentou a conversão alimentar reduziu.

Tabela 2. Acúmulo de gordura abdominal de frangos de corte alimentados com dietas com diferentes relações energia-proteína de 1 a 49 dias de idade

\begin{tabular}{ccc}
\hline Energia-proteína & \multicolumn{3}{c}{ Gordura Abdominal } \\
& $(\mathrm{g})$ & $(\%)$ \\
\hline 158,3 & $28,0^{\mathrm{c}}$ & $1,42^{\mathrm{c}}$ \\
166,3 & $37,1^{\mathrm{bc}}$ & $1,80^{\mathrm{bc}}$ \\
171,4 & $39,3^{\mathrm{bc}}$ & $1,91^{\mathrm{abc}}$ \\
176,4 & $52,4^{\mathrm{a}}$ & $2,47^{\mathrm{a}}$ \\
181,2 & $48,9^{\mathrm{ab}}$ & $2,28^{\mathrm{ab}}$ \\
\hline
\end{tabular}

Fonte: Dutra Jr. et al.(1991)

${ }^{a b c}$ Diferem estatisticamente na mesma coluna $(p<0,01)$

No entanto, observa-se que o estreitamento da relação energia-proteína reduz a quantidade de gordura abdominal acumulada na carcaça de frangos de corte. Ficou evidente que o aumento da suplementação de gordura na dieta melhorou a conversão alimentar, mas aumentou o acúmulo de gordura abdominal em frangos de corte.

A influência dos níveis de gordura na dieta no acúmulo de gordura foi determinada por Junqueira et al. (2002), utilizando-se dietas isocalóricas e isoproteínas com alteração apenas no nível de inclusão de óleo de soja nas dietas, procedimento diferente adotado por Dutra Jr. et al. (1991) (Tabela 3). 
Tabela 3. Rendimento de carcaça (RC), rendimento de peito (RP), rendimento de coxa+sobrecoxa (RCSC), e gordura abdominal (GA) em frangos de corte de 42 dias com quatro níveis de óleo de soja

\begin{tabular}{cccccc}
\hline Características & \multicolumn{5}{c}{ Níveis de óleo de soja } \\
$(\%)$ & 0,0 & 3,3 & 6,6 & 9,9 & CV (\%) \\
\hline RC & 68,0 & 68,0 & 67,7 & 67,5 & 1,69 \\
RP & 34,9 & 34,4 & 34,7 & 34,3 & 3,79 \\
RCSC & 31,3 & 31,9 & 31,4 & 30,9 & 4,11 \\
GA $^{*}$ & 1,92 & 2,34 & 2,56 & 2,40 & 24,20 \\
\hline
\end{tabular}

Fonte: Junqueira et al. (2002)

* efeito quadrático $(p<0,05)$

O rendimento de carcaça e suas parte não foram influenciados pelos níveis de gorduras suplementados, apenas a gordura abdominal teve um efeito quadrático, mas sem nenhuma explicação plausível para tal efeito. Nota-se que a suplementação de gordura, mesmo em níveis baixos, eleva o acúmulo de gordura na carcaça quando comparadas à dieta sem suplementação.

A suplementação de diferentes gorduras nas dietas de frangos de corte foi avaliada por Crespo \& Esteve-Garcia (2001) e mostrou-se influente no acúmulo de gordura. No entanto, estes autores não utilizaram dietas isoenergéticas e isoproteícas, corrigida a energia metabolizável para as gorduras utilizadas (Tabela 4). 
Tabela 4. Ganho de peso (GP), consumo de ração (CR), conversão alimentar (CA) e acúmulo de gordura abdominal (GA) de frangos de corte alimentados com dietas contendo vários tipos de gordura

\begin{tabular}{lccccc}
\hline Gordura & \multicolumn{5}{c}{ Machos aos 42 dias de idade } \\
& GP $(\mathrm{g})$ & CR $(\mathrm{g})$ & CA & GA $(\mathrm{g})$ & GA $(\%)$ \\
\hline Sebo Bovino & 2595 & $3770^{\mathrm{a}}$ & $2,03^{\mathrm{a}}$ & $54,18^{\mathrm{a}}$ & $2,00^{\mathrm{a}}$ \\
Óleo de Oliva & 2580 & $3649^{\mathrm{b}}$ & $1,98^{\mathrm{b}}$ & $54,82^{\mathrm{a}}$ & $2,07^{\mathrm{a}}$ \\
Óleo de Girassol & 2606 & $3490^{\mathrm{c}}$ & $1,87^{\mathrm{c}}$ & $45,46^{\mathrm{b}}$ & $1,70^{\mathrm{b}}$ \\
Óleo de linhaça & 2592 & $3476^{\mathrm{c}}$ & $1,88^{\mathrm{c}}$ & $46,94^{\mathrm{b}}$ & $1,75^{\mathrm{b}}$
\end{tabular}

Fonte: Crespo \& Esteve-Garcia (2001)

${ }^{a, b, c}$ Diferem estatisticamente na mesma coluna $(p<0,001)$

A não correção da energia metabolizável das gorduras pelos autores, adicionando 6 ou $10 \%$ a dieta, levam a uma distorção dos resultados de desempenho e acúmulo de gordura, provavelmente o óleo de girassol e o óleo de linhaça possuem mais energia, consumindo menos ração, melhorando a conversão alimentar e acumulando menos gordura na carcaça. Zollitsch et al. (1997) adicionaram 3,5\% de misturas comerciais de gorduras e obtiveram diferenças no desempenho e acúmulo de gordura abdominal, novamente sem considerar a energia contida em nas gorduras.

Gaiotto et al. (2000) mostraram que a adição de diferentes gorduras a $4 \%$ nas dietas afeta o desempenho de frangos de corte e o acúmulo de gordura devido ao diferencial de energia contida nas mesmas. Avaliar os tipos de gordura suplementadas as dietas de frangos de corte sem uma prévia determinação de energia, com interação dos conhecimentos específicos de digestão e absorção das gorduras, implicará em avaliações grosseiras e infundadas.

A finalidade deste trabalho foi determinar o ganho de peso (GP), consumo de ração $(C R)$, conversão alimentar (CA) e viabilidade (VB), bem como o rendimento de carcaça e partes de frangos de corte alimentados com 
dietas formuladas a partir de energias metabolizáveis pré-determinadas do óleo ácido (OA), óleo de soja (OS), óleo de vísceras de aves (OV), 75\% de óleo ácido com $25 \%$ de óleo de soja (OA75/OS25), 50\% de óleo ácido com $50 \%$ de óleo de soja (OA50/OS50) e 50\% óleo de vísceras de aves com 50\% de óleo de soja (OV50/OS50), nas fases pré-inicial (0-7 dias de idade), inicial (8-21 dias), crescimento (22-35 dias) e final (36-42 dias).

\subsection{Material e Métodos}

Foi realizado um experimento para determinar o ganho de peso (GP), consumo de ração (CR), conversão alimentar (CA) e viabilidade (VB) de frangos de corte, bem como o rendimento de carcaça e partes. O galpão experimental tem comprimento de $32 \mathrm{~m}$ por $8 \mathrm{~m}$ de largura, equipado com cortinas superiores e laterais. Há duas portas, sendo que uma dá acesso ao corredor central, de $2 \mathrm{~m}$ de largura, e a outra dá acesso à área de serviço de $28 \mathrm{~m}^{2}$, utilizada para armazenamento das rações. O galpão possui 36 boxes experimentais, dispostos em duas fileiras longitudinais com 18 divisórias cada, onde serão instaladas as parcelas. Cada boxe possui uma área de 4,5 $\mathrm{m}^{2}$ e uma porta de acesso ao corredor central.

Para cada boxe foi utilizada uma lâmpada de aquecimento, mantida até o $14^{\circ}$ dia de experimentação, além de 6 aquecedores a gás distribuídos ao longo do corredor central. Nos boxes havia um comedouro de $5 \mathrm{~kg}$ de capacidade para pintos, utilizado até o $14^{\circ}$ dia de idade, e um bebedouro para pintos, mantido até $05^{\circ}$ dia de experimentação, além de duas placas de madeira para reduzir a área de movimentação das aves e prover um melhor controle da temperatura ambiente.

No $6^{\circ}$ dia de idade os bebedouros de pintos foram substituídos por bebedouros pendulares, no $14^{\circ}$ dia foram substituídos os comedouros de 5 $\mathrm{kg}$ pelos de $25 \mathrm{~kg}$ de capacidade e retiradas as placas de madeira. 
Foram utilizadas duas balanças para as pesagens semanais das rações e aves. Dois termômetros dispostos no corredor central, utilizados para registrar a temperatura máxima e mínima, durante todo período experimental. Foi utilizado como cama para as aves uma mistura de maravalha de madeira e casca de arroz, espalhados homogeneamente por todo a divisória.

No primeiro dia de experimentação, após a chegada dos pintos, verificou-se individualmente a sexagem, estado físico e a sanidade dos mesmos. Em seguida as aves foram pesadas, divididas em sublotes de 40 aves e distribuídas nos boxes de forma homogênea conforme seu peso. O peso médio inicial das aves foi de $43,5 \mathrm{~g}$. Água e ração foram fornecidas à vontade durante todo período experimental.

Tanto as aves como as rações foram pesadas semanalmente até os 42 dias de idade. A mortalidade foi registrada diariamente e as aves mortas foram pesadas para correção da conversão alimentar e do consumo de ração.

Os 6 tratamentos utilizados no experimento foram selecionados a partir dos experimentos de metabolismo. O primeiro critério de seleção foi a utilização das gorduras individualmente, definindo o óleo ácido (OA), óleo de soja (OS) e óleo de vísceras de aves (OV) como tratamentos. O segundo critério foi selecionar entre as gorduras aquelas que apresentaram um ganho energético quando misturadas. Foram selecionadas as misturas: $75 \%$ de óleo ácido com $25 \%$ de óleo de soja (OA75/OS25) e 50\% de óleo ácido com $50 \%$ de óleo de soja (OA50/OS50). No terceiro, o critério de seleção das gorduras foi a inclusão de uma mistura com óleo de vísceras de aves, sendo selecionada a mistura: $50 \%$ óleo de vísceras de aves com $50 \%$ de óleo de soja (OV50/OS50). Foram utilizados 6 repetições distribuídas em blocos casualizados. Utilizaram-se 40 aves por parcela, totalizando 1440 pintos de corte machos da linhagem AgRoss, alimentadas com rações isoproteícas e isoenergéticas, conforme mostram as Tabelas $7,8,9$, e 10. As rações foram divididas em 4 fases: pré-inicial ( $0-7$ dias), inicial ( $8-21$ dias), crescimento (22 - 35 dias) e final (36 - 42 dias). Aos 42 dias de idade foram escolhidas 4 
aves por parcela dentro da faixa do peso médio da parcela $\pm 10 \%$ para abate. Foi determinado o peso em jejum, o peso da carcaça (PCar), peso do fígado (PFígado), peso da gordura abdominal acumulada (PGAb), peso do peito (PPei), peso da coxa (PCox) e sobrecoxa (PSob), assim como os rendimentos relativos ao peso vivo no abate, o rendimento de carcaça (RCar), o fígado (Fígado), a porcentagem gordura abdominal acumulada (\%GAb), o rendimento do peito (RPei), o rendimento da coxa (RCox) e o rendimento da sobrecoxa (RSob). A análide de variância foi realizada pelo procedimento PROC GLM (Genral Linear Models) do programa Statistical Analysis System, 1989. A comparação de médias foram realizadas pelo teste de Tukey $(p<0,05)$.

As gorduras utilizadas nos experimentos foram o óleo de soja, o óleo ácido e a gordura de frango analisadas no laboratório CBOneida Ltda ME, seguindo a metodologia proposta por Silva (1990) (Tabelas 5 e 6).

Tabela 5. Análise de qualidade das gorduras

\begin{tabular}{lcccc}
\hline Análises & Unidade & Óleo soja & Óleo ácido & Óleo vísceras \\
\hline Umidade & $\%$ & 0,17 & 1,5 & 4,95 \\
Extrato Etéreo & $\%$ & 99,19 & 97,3 & 95,01 \\
Índice Peróxido & $\mathrm{mEq} / \mathrm{kg}$ & 0,0 & 0,0 & 0,0 \\
Índice Acidez & $\mathrm{gNaOH} / \mathrm{g}$ & 0,02 & 0,43 & 0,03 \\
Energia Bruta & $\mathrm{kcal} / \mathrm{kg}$ & 9495 & 8821 & 8793 \\
\hline
\end{tabular}


Tabela 6. Perfil de ácidos graxos das gorduras, em \% ácidos graxos totais

\begin{tabular}{lccc}
\hline Ácidos graxos & \multicolumn{3}{c}{$\%$ ácidos graxos totais } \\
& Óleo de soja & Óleo ácido & Óleo de vísceras \\
\hline 16:0 (palmítico) & 14,8 & 24,74 & 25,66 \\
18:0 (esteárico) & 3,11 & 3,90 & 6,66 \\
16:1 (palmitoleico) & 0,31 & 1,56 & 7,28 \\
18:1 $\omega 9$ (oleico) & 23,79 & 31,4 & 44,53 \\
18:2 $\omega 6$ (linoléico) & 51,36 & 0,41 & 1,38 \\
18:3 $\omega 3$ (linolênico) & 5,82 & 15,14 & 5,87 \\
20:0 (aráquico) & 0,22 & 13,80 & 4,99 \\
Saturados & 18,13 & 46,28 & 37,94 \\
Insaturados & 81,52 & 53,58 & 61,38 \\
Polinsaturados & 57,18 & 15,55 & 7,25 \\
\hline
\end{tabular}


Tabela 7. Composição das dietas na fase pré-inicial

\begin{tabular}{|c|c|c|c|c|c|c|}
\hline Ingredientes, \% & $O A^{3}$ & $\mathrm{OS}^{3}$ & $\mathrm{OV}^{3}$ & $\begin{array}{l}\text { OA75/ } \\
\text { OS } 25^{3}\end{array}$ & $\begin{array}{l}\text { OA50/ } \\
\text { OS50 }^{3}\end{array}$ & $\begin{array}{l}\text { OV50/ } \\
\text { OS50 }^{3}\end{array}$ \\
\hline Milho & 47,06 & 49,37 & 49,11 & 48,36 & 49,32 & 49,17 \\
\hline Farelo de soja & 43,15 & 42,72 & 42,77 & 42,91 & 42,73 & 42,76 \\
\hline Óleo ácido (OA) & 5,86 & - & - & - & - & - \\
\hline Óleo de soja (OS) & - & 3,98 & - & - & - & - \\
\hline Óleo de vísceras (OV) & - & - & 4,19 & - & - & - \\
\hline $75 \%$ OA com $25 \%$ OS & - & - & - & 4,80 & - & - \\
\hline $50 \%$ OA com $50 \%$ OS & - & - & - & - & 4,02 & - \\
\hline $50 \%$ OV com $50 \%$ OS & - & - & - & - & - & 4,14 \\
\hline Fosfato bicálcico & 1,87 & 1,86 & 1,86 & 1,86 & 1,86 & 1,86 \\
\hline Calcário calcítico & 0,96 & 0,97 & 0,97 & 0,97 & 0,97 & 0,97 \\
\hline Sal & 0,50 & 0,50 & 0,50 & 0,50 & 0,50 & 0,50 \\
\hline DL- Metionina & 0,20 & 0,20 & 0,20 & 0,20 & 0,20 & 0,20 \\
\hline Suplemento vitamínico ${ }^{1}$ & 0,30 & 0,30 & 0,30 & 0,30 & 0,30 & 0,30 \\
\hline Suplemento mineral $^{2}$ & 0,05 & 0,05 & 0,05 & 0,05 & 0,05 & 0,05 \\
\hline Cloreto colina $60 \%$ & 0,05 & 0,05 & 0,05 & 0,05 & 0,05 & 0,05 \\
\hline Nutrientes & \multicolumn{6}{|c|}{ Níveis calculados } \\
\hline EM (kcal/kg) & 2960 & 2960 & 2960 & 2960 & 2960 & 2960 \\
\hline PB (\%) & 24,0 & 24,0 & 24,0 & 24,0 & 24,0 & 24,0 \\
\hline Met. + cis. (\%) & 0,92 & 0,92 & 0,92 & 0,92 & 0,92 & 0,92 \\
\hline Lisina (\%) & 1,31 & 1,31 & 1,31 & 1,31 & 1,31 & 1,31 \\
\hline Fósforo disp. (\%) & 0,46 & 0,46 & 0,46 & 0,46 & 0,46 & 0,46 \\
\hline Cálcio (\%) & 0,98 & 0,98 & 0,98 & 0,98 & 0,98 & 0,98 \\
\hline
\end{tabular}

1-Concentração por kg de ração: Ácido fólico, $1 \mathrm{mg}$; ácido pantotênico, $15 \mathrm{mg}$; antioxidante, 22,5 mg; biotina, $60 \mathrm{mg}$; colina, $400 \mathrm{mg}$; niacina, $40 \mathrm{mg}$; selênio, $0,3 \mathrm{mg}$; vitamina $A$, $8.000 \mathrm{UI}$; vitamina $B_{1}, 1,8$ $\mathrm{mg}$; vitamina $B_{12}, 12 \mathrm{mcg}$; vitamina $B_{2}, 6 \mathrm{mg}$; vitamina $B_{6}, 2 ., 8 \mathrm{mg}$; vitamina $D_{3}, 2.000 \mathrm{Ul}$; vitamina $E, 15$ $\mathrm{UI}$; vitamina $\mathrm{K}, 1,8 \mathrm{mg}$.

2-Concentração por kg de ração: Manganês, 75 mg; cobre, 8 mg; zinco, 50 mg; ferro, 50 mg; iodo, 0,75 $\mathrm{mg}$

3-Olaquindox ,40 mg/kg, Avilamicina, 5 mg/kg, Nicarbazina, 110 mg/kg; 
Tabela 8. Composição das dietas na fase inicial

\begin{tabular}{|c|c|c|c|c|c|c|}
\hline Ingredientes, \% & $O A^{3}$ & $\mathrm{OS}^{3}$ & $O V^{3}$ & $\begin{array}{l}\text { OA75/ } \\
\text { OS25 }\end{array}$ & $\begin{array}{l}\text { OA50/ } \\
\text { OS50 }^{3}\end{array}$ & $\begin{array}{l}\text { OV50/ } \\
\text { OS50 }^{3}\end{array}$ \\
\hline Milho & 56,69 & 58,62 & 58,30 & 57,77 & 58,39 & 58,28 \\
\hline Farelo de soja & 35,31 & 34,94 & 35,00 & 35,10 & 34,99 & 35,0 \\
\hline Óleo ácido (OA) & 3,90 & - & - & - & - & - \\
\hline Óleo de soja (OS) & - & 2,34 & - & - & - & - \\
\hline Óleo de vísceras (OV) & - & - & 2,60 & - & - & - \\
\hline $75 \%$ OA com $25 \%$ OS & - & - & - & 3,03 & - & - \\
\hline $50 \%$ OA com $50 \%$ OS & - & - & - & - & 2,52 & - \\
\hline $50 \%$ OV com $50 \%$ OS & - & - & - & - & - & 2,62 \\
\hline Fosfato bicálcico & 1,82 & 1,82 & 1,82 & 1,82 & 1,82 & 1,82 \\
\hline Calcário calcítico & 0,98 & 0,98 & 0,98 & 0,98 & 0,98 & 0,98 \\
\hline Sal & 0,50 & 0,50 & 0,50 & 0,50 & 0,50 & 0,50 \\
\hline Lisina. $\mathrm{HCl}$ & 0,17 & 0,18 & 0,18 & 0,18 & 0,18 & 0,18 \\
\hline DL- Metionina & 0,24 & 0,23 & 0,23 & 0,23 & 0,23 & 0,23 \\
\hline Suplemento vitamínico ${ }^{1}$ & 0,30 & 0,30 & 0,30 & 0,30 & 0,30 & 0,30 \\
\hline Suplemento mineral ${ }^{2}$ & 0,05 & 0,05 & 0,05 & 0,05 & 0,05 & 0,05 \\
\hline Cloreto colina $60 \%$ & 0,04 & 0,04 & 0,04 & 0,04 & 0,04 & 0,04 \\
\hline Nutrientes & \multicolumn{6}{|c|}{ Níveis calculados } \\
\hline EM (kcal/kg) & 3000 & 3000 & 3000 & 3000 & 3000 & 3000 \\
\hline PB (\%) & 21,4 & 21,4 & 21,4 & 21,4 & 21,4 & 21,4 \\
\hline Met. + cis. (\%) & 0,89 & 0,89 & 0,89 & 0,89 & 0,89 & 0,89 \\
\hline Lisina (\%) & 1,26 & 1,26 & 1,26 & 1,26 & 1,26 & 1,26 \\
\hline Fósforo disp. (\%) & 0,45 & 0,45 & 0,45 & 0,45 & 0,45 & 0,45 \\
\hline Cálcio (\%) & 0,96 & 0,96 & 0,96 & 0,96 & 0,96 & 0,96 \\
\hline
\end{tabular}

1-Concentração por kg de ração: Ácido fólico, $1 \mathrm{mg}$; ácido pantotênico, $15 \mathrm{mg}$; antioxidante, 22,5 mg; biotina, $60 \mathrm{mg}$; colina, $400 \mathrm{mg}$; niacina, $40 \mathrm{mg}$; selênio, $0,3 \mathrm{mg}$; vitamina $A$, $8.000 \mathrm{Ul}$; vitamina $B_{1}, 1,8$ mg; vitamina $B_{12}, 12$ mcg; vitamina $B_{2}, 6 \mathrm{mg}$; vitamina $B_{6}, 2 ., 8 \mathrm{mg}$; vitamina $D_{3}, 2.000 \mathrm{Ul}$; vitamina $E, 15$ UI; vitamina $\mathrm{K}, 1,8 \mathrm{mg}$.

2-Concentração por kg de ração: Manganês, 75 mg; cobre, 8 mg; zinco, 50 mg; ferro, 50 mg; iodo, $0,75 \mathrm{mg}$.

3-Olaquindox, 40mg/kg, Avilamicina, $5 \mathrm{mg} / \mathrm{kg}$, Nicarbazina, 110mg/kg. 
Tabela 9. Composição das dietas na fase de crescimento

\begin{tabular}{|c|c|c|c|c|c|c|}
\hline Ingredientes, \% & $O A^{3}$ & $\mathrm{OS}^{3}$ & $O V^{3}$ & $\begin{array}{l}\text { OA75/ } \\
\text { OS25 }\end{array}$ & $\begin{array}{l}\text { OA50/ } \\
\text { OS50 }^{3}\end{array}$ & $\begin{array}{l}\text { OV50/ } \\
\text { OS50 }\end{array}$ \\
\hline $\begin{array}{l}\text { Milho } \\
\end{array}$ & 61,64 & 62,88 & 62,79 & 62,01 & 62,57 & 62,56 \\
\hline Farelo de soja & 30,30 & 30,07 & 30,08 & 30,23 & 30,13 & 30,13 \\
\hline Óleo ácido (OA) & 4,22 & - & - & - & - & - \\
\hline Óleo de soja (OS) & - & 3,21 & - & - & - & - \\
\hline Óleo de vísceras (OV) & - & - & 3,29 & - & - & - \\
\hline $75 \%$ OA com $25 \%$ OS & - & - & - & 3,92 & - & - \\
\hline $50 \%$ OA com $50 \%$ OS & - & - & - & - & 3,46 & - \\
\hline $50 \%$ OV com $50 \%$ OS & - & - & - & - & - & 3,47 \\
\hline Fosfato bicálcico & 1,61 & 1,61 & 1,61 & 1,61 & 1,61 & 1,61 \\
\hline Calcário calcítico & 0,93 & 0,93 & 0,93 & 0,93 & 0,93 & 0,93 \\
\hline Sal & 0,50 & 0,50 & 0,50 & 0,50 & 0,50 & 0,50 \\
\hline Lisina. $\mathrm{HCl}$ & 0,20 & 0,20 & 0,20 & 0,20 & 0,20 & 0,20 \\
\hline DL- Metionina & 0,21 & 0,21 & 0,21 & 0,21 & 0,21 & 0,21 \\
\hline Suplemento vitamínico ${ }^{1}$ & 0,30 & 0,30 & 0,30 & 0,30 & 0,30 & 0,30 \\
\hline Suplemento mineral $\left.\right|^{2}$ & 0,05 & 0,05 & 0,05 & 0,05 & 0,05 & 0,05 \\
\hline Cloreto colina $60 \%$ & 0,04 & 0,04 & 0,04 & 0,04 & 0,04 & 0,04 \\
\hline Nutrientes & \multicolumn{6}{|c|}{ Níveis calculados } \\
\hline EM (kcal/kg) & 3100 & 3100 & 3100 & 3100 & 3100 & 3100 \\
\hline PB (\%) & 19,5 & 19,5 & 19,5 & 19,5 & 19,5 & 19,5 \\
\hline Met. + cis. $(\%)$ & 0,82 & 0,82 & 0,82 & 0,82 & 0,82 & 0,82 \\
\hline Lisina (\%) & 1,15 & 1,15 & 1,15 & 1,15 & 1,15 & 1,15 \\
\hline Fósforo disp. (\%) & 0,40 & 0,40 & 0,40 & 0,40 & 0,40 & 0,40 \\
\hline Cálcio (\%) & 0,87 & 0,87 & 0,87 & 0,87 & 0,87 & 0,87 \\
\hline
\end{tabular}

1-Concentração por kg de ração: Ácido fólico, 0,7 mg; ácido pantotênico, 13mg; antioxidante, 15g; colina, $300 \mathrm{mg}$; niacina, 3,5mg; selênio, $0,3 \mathrm{mg}$; vitamina $A, 7.000 \mathrm{Ul}$; vitamina $B_{1}, 1,6 \mathrm{mg}$; vitamina $B_{12}$, 10 mcg; vitamina $B_{2}, 5 \mathrm{mg}$; vitamina $B_{6}, 2,6$ mg; vitamina $D_{3}, 1.500 \mathrm{Ul}$; vitamina $E$, $12 \mathrm{Ul}$; vitamina $\mathrm{K}, 1,5$ $\mathrm{mg}$.

2-Concentração por kg de ração: Manganês, 75 mg; cobre, 8 mg; zinco, 50 mg; ferro, 50 mg; iodo, 0,75 $\mathrm{mg}$

3- Olaquindox, 40mg/kg, Avilamicina, 5 mg/kg, Salinomicina 12\%, 66 mg/kg, Ácido 3-nitro, 35 mg/kg. 
Tabela 10. Composição das dietas da fase final

\begin{tabular}{|c|c|c|c|c|c|c|}
\hline Ingredientes, \% & $O A^{3}$ & $\mathrm{OS}^{3}$ & $O V^{3}$ & $\begin{array}{l}\text { OA75/ } \\
\text { OS } 25^{3}\end{array}$ & $\begin{array}{l}\text { OA50/ } \\
\text { OS50 }^{3}\end{array}$ & $\begin{array}{l}\text { OV50/ } \\
\text { OS50 }\end{array}$ \\
\hline Milho & 64,35 & 65,91 & 65,82 & 65,04 & 65,52 & 65,46 \\
\hline Farelo de soja & 26,48 & 26,19 & 26,20 & 26,35 & 26,26 & 26,27 \\
\hline Óleo ácido (OA) & 5,33 & - & - & - & - & - \\
\hline Óleo de soja (OS) & - & 4,06 & - & - & - & - \\
\hline Óleo de vísceras (OV) & - & - & 4,14 & - & - & - \\
\hline $75 \%$ OA com $25 \%$ OS & - & - & - & 4,77 & - & - \\
\hline $50 \%$ OA com $50 \%$ OS & - & - & - & - & 4,38 & - \\
\hline $50 \%$ OV com $50 \%$ OS & - & - & - & - & - & 4,43 \\
\hline Fosfato bicálcico & 1,47 & 1,47 & 1,47 & 1,47 & 1,47 & 1,47 \\
\hline Calcário calcítico & 1,04 & 1,04 & 1,04 & 1,04 & 1,04 & 1,04 \\
\hline Sal & 0,50 & 0,50 & 0,50 & 0,50 & 0,50 & 0,50 \\
\hline Lisina. $\mathrm{HCl}$ & 0,24 & 0,24 & 0,24 & 0,24 & 0,24 & 0,24 \\
\hline DL- Metionina & 0,20 & 0,20 & 0,20 & 0,20 & 0,20 & 0,20 \\
\hline Suplemento vitamínico ${ }^{1}$ & 0,30 & 0,30 & 0,30 & 0,30 & 0,30 & 0,30 \\
\hline Suplemento mineral $^{2}$ & 0,05 & 0,05 & 0,05 & 0,05 & 0,05 & 0,05 \\
\hline Cloreto colina $60 \%$ & 0,04 & 0,04 & 0,04 & 0,04 & 0,04 & 0,04 \\
\hline Nutrientes & \multicolumn{6}{|c|}{ Níveis calculados } \\
\hline EM (kcal/kg) & 3200 & 3200 & 3200 & 3200 & 3200 & 3200 \\
\hline PB (\%) & 18,0 & 18,0 & 18,0 & 18,0 & 18,0 & 18,0 \\
\hline Met. + cis. $(\%)$ & 0,77 & 0,77 & 0,77 & 0,77 & 0,77 & 0,77 \\
\hline Lisina (\%) & 1,08 & 1,08 & 1,08 & 1,08 & 1,08 & 1,08 \\
\hline Fósforo disp. (\%) & 0,37 & 0,37 & 0,37 & 0,37 & 0,37 & 0,37 \\
\hline Cálcio (\%) & 0,87 & 0,87 & 0,87 & 0,87 & 0,87 & 0,87 \\
\hline
\end{tabular}

1-Concentração kg ração: Ácido fólico, 0,7 mg; ácido pantotênico, 13mg; antioxidante, 15g; colina, 300 $\mathrm{mg}$; niacina, 3,5mg; selênio, 0,3 mg; vitamina $A, 7.000 \mathrm{UI}$; vitamina $B_{1}, 1,6 \mathrm{mg}$; vitamina $B_{12}, 10 \mathrm{mcg}$; vitamina $B_{2}, 5 \mathrm{mg}$; vitamina $B, 62,6 \mathrm{mg}$; vitamina $D_{3}, 1.500 \mathrm{Ul}$; vitamina $\mathrm{E}, 12 \mathrm{UI}$; vitamina $\mathrm{K}, 1,5 \mathrm{mg}$. 2-Concentração kg ração: Manganês $75 \mathrm{mg}$; cobre $8 \mathrm{mg}$; zinco $50 \mathrm{mg}$; ferro $50 \mathrm{mg}$; iodo $0,75 \mathrm{mg}$ 3- Olaquindox, 40mg/kg, Avilamicina, $5 \mathrm{mg} / \mathrm{kg}$, Salinomicina 12\%, $66 \mathrm{mg} / \mathrm{kg}$, Ácido 3-nitro, $35 \mathrm{mg} / \mathrm{kg}$. 


\subsection{Resultados e Discussão}

Os resultados referentes ao desempenho de frangos de corte aos 7 dias de idade estão apresentados na Tabela 11. O GP dos frangos de corte alimentados com o OS foi inferior $(p<0,05)$ ao $A 075 / O S 25$, mas não se diferenciou dos demais tratamentos. Não houve diferença significativa no CR entre os tratamentos. A CA mostrou-se pior para o OS diferenciando-se do A075/OS25, influência direta do baixo GP obtido pelo OS. Não houve diferença significativa na VB entre os tratamentos.

Tabela 11. Desempenho de frangos de corte aos 7 dias de idade

\begin{tabular}{lcccc}
\hline Tratamentos & GP $(\mathrm{kg})$ & CR $(\mathrm{kg})$ & CA & VB (\%) \\
\hline OA & $0,161^{\mathrm{ab}}$ & $0,164^{\mathrm{a}}$ & $1,01^{\mathrm{ab}}$ & $100,0^{\mathrm{a}}$ \\
OS & $0,156^{\mathrm{b}}$ & $0,161^{\mathrm{a}}$ & $1,03^{\mathrm{b}}$ & $100,0^{\mathrm{a}}$ \\
OV & $0,161^{\mathrm{ab}}$ & $0,163^{\mathrm{a}}$ & $1,01^{\mathrm{ab}}$ & $100,0^{\mathrm{a}}$ \\
OA75/OS25 & $0,165^{\mathrm{a}}$ & $0,160^{\mathrm{a}}$ & $0,96^{\mathrm{a}}$ & $100,0^{\mathrm{a}}$ \\
OA50/OS50 & $0,160^{\mathrm{ab}}$ & $0,160^{\mathrm{a}}$ & $1,00^{\mathrm{ab}}$ & $100,0^{\mathrm{a}}$ \\
OV50/OS50 & $0,160^{\mathrm{ab}}$ & $0,161^{\mathrm{a}}$ & $1,00^{\mathrm{ab}}$ & $99,5^{\mathrm{a}}$ \\
CV (\%) & 3,14 & 4,89 & 4,28 & 0,41 \\
\hline a,b,c Diferem estatisticamente na mesma coluna $(\mathrm{p}>0,05)$ & &
\end{tabular}

Na Tabela 12 são apresentados os resultados referentes ao desempenho de frangos de corte aos 14 dias de idade. O GP do OS foi inferior ao OA, OA75/OS25 e ao OA50/OS50, mas não se diferenciou do demais tratamentos. O GP do OA50/OS50 foi superior $(p<0,05)$ ao OV50/OS50 e não se diferenciou do OA, OV e OA75/OS25. O CR de ração do OS foi inferior aos demais tratamentos. A CA foi significativamente $(p<0,05)$ pior para o OV50/OS50 em relação ao OA, OS e OA75/OS25, mas não se diferenciou do OV e OA50/OS50. Não houve diferença significativa da VB entre os tratamentos. 
Tabela 12. Desempenho de frangos de corte aos 14 dias de idade

\begin{tabular}{lcccc}
\hline Tratamentos & GP $(\mathrm{kg})$ & CR(kg) & CA & VB (\%) \\
\hline OA & $0,349^{\mathrm{ab}}$ & $0,435^{\mathrm{a}}$ & $1,24^{\mathrm{a}}$ & $99,1^{\mathrm{a}}$ \\
OS & $0,323^{\mathrm{c}}$ & $0,387^{\mathrm{b}}$ & $1,19^{\mathrm{a}}$ & $99,1^{\mathrm{a}}$ \\
OV & $0,343^{\mathrm{abc}}$ & $0,433^{\mathrm{a}}$ & $1,26^{\mathrm{ab}}$ & $99,5^{\mathrm{a}}$ \\
OA75/OS25 & $0,360^{\mathrm{ab}}$ & $0,436^{\mathrm{a}}$ & $1,20^{\mathrm{a}}$ & $99,1^{\mathrm{a}}$ \\
OA50/OS50 & $0,361^{\mathrm{a}}$ & $0,453^{\mathrm{a}}$ & $1,25^{\mathrm{ab}}$ & $100,0^{\mathrm{a}}$ \\
OV50/OS50 & $0,340^{\mathrm{bc}}$ & $0,452^{\mathrm{a}}$ & $1,32^{\mathrm{b}}$ & $99,5^{\mathrm{a}}$ \\
CV (\%) & 3,04 & 4,16 & 3,36 & 1,24 \\
\hline a,b,c Diferem estatisticamente na mesma coluna (p>0,05) & &
\end{tabular}

A Tabela 13 apresenta o desempenho de frangos de corte aos 21 dias de idade. O GP do OS mostrou-se inferior as misturas de goduras, mas não se diferenciou do OA e OV. O CR para o OS foi inferior a todos os tratamentos, seguido pelo inferior consumo do OA em relação ao OV50/OS50. O CR do OA não se diferenciou do OV, OA75/OS25 e do OA50/OS50. A CA do OS foi melhor ao OV e ao OV50/OS50, não se diferenciando dos demais tratamentos. A CA do OV50/OS50 foi superior a todos os tratamentos, com exceção do OV. Não houve diferença significativa da VB entre os tratamentos.

Tabela 13. Desempenho de frangos de corte aos 21 dias de idade

\begin{tabular}{lcccc}
\hline Tratamentos & GP $(\mathrm{kg})$ & CR $(\mathrm{kg})$ & CA & VB (\%) \\
\hline OA & $0,721^{\mathrm{ab}}$ & $0,996^{\mathrm{b}}$ & $1,37^{\mathrm{ab}}$ & $97,9^{\mathrm{a}}$ \\
OS & $0,695^{\mathrm{b}}$ & $0,935^{\mathrm{c}}$ & $1,34^{\mathrm{a}}$ & $98,3^{\mathrm{a}}$ \\
OV & $0,732^{\mathrm{ab}}$ & $1,032^{\mathrm{ab}}$ & $1,39^{\mathrm{bc}}$ & $97,5^{\mathrm{a}}$ \\
OA75/OS25 & $0,745^{\mathrm{a}}$ & $1,021^{\mathrm{ab}}$ & $1,36^{\mathrm{ab}}$ & $98,75^{\mathrm{a}}$ \\
OA50/OS50 & $0,757^{\mathrm{a}}$ & $1,040^{\mathrm{ab}}$ & $1,36^{\mathrm{ab}}$ & $100,0^{\mathrm{a}}$ \\
OV50/OS50 & $0,734^{\mathrm{a}}$ & $1,050^{\mathrm{a}}$ & $1,42^{\mathrm{c}}$ & $98,7^{\mathrm{a}}$ \\
CV (\%) & 2,94 & 2,93 & 1,91 & 2,58 \\
\hline a,b,c Diferem estatisticamente na mesma coluna $(\mathrm{p}>0,05)$ & &
\end{tabular}


Na Tabela 14 é mostrado o resultado do desempenho de frangos de corte aos 28 dia de idade. O GP do OS foi inferior aos demais tratamentos, assim como o CR de ração. A CA do OV50/OS50 mostrou pior aos demais tratamentos. Não houve diferença significativa na VB entre os tratamentos.

Tabela 14. Desempenho de frangos de corte aos 28 dias de idade

\begin{tabular}{lcccc}
\hline Tratamentos & GP $(\mathrm{kg})$ & CR $(\mathrm{kg})$ & CA & VB (\%) \\
\hline OA & $1,325^{\mathrm{a}}$ & $1,943^{\mathrm{a}}$ & $1,46^{\mathrm{a}}$ & $97,0^{\mathrm{a}}$ \\
OS & $1,252^{\mathrm{b}}$ & $1,826^{\mathrm{b}}$ & $1,45^{\mathrm{a}}$ & $97,9^{\mathrm{a}}$ \\
OV & $1,334^{\mathrm{a}}$ & $1,989^{\mathrm{a}}$ & $1,48^{\mathrm{a}}$ & $97,0^{\mathrm{a}}$ \\
OA75/OS25 & $1,360^{\mathrm{a}}$ & $1,987^{\mathrm{a}}$ & $1,45^{\mathrm{a}}$ & $98,3^{\mathrm{a}}$ \\
OA50/OS50 & $1,324^{\mathrm{a}}$ & $1,960^{\mathrm{a}}$ & $1,47^{\mathrm{a}}$ & $99,5^{\mathrm{a}}$ \\
OV50/OS50 & $1,311^{\mathrm{a}}$ & $2,028^{\mathrm{a}}$ & $1,54^{\mathrm{b}}$ & $98,3^{\mathrm{a}}$ \\
CV (\%) & 2,51 & 2,63 & 1,83 & 2,62 \\
\hline a,b,c Diferem estatisticamente na mesma coluna $(\mathrm{p}>0,05)$ & &
\end{tabular}

$\mathrm{Na}$ tabela 15 são mostrados os resultados dos tratamentos com gorduras adicionadas as rações aos 35 dias de idade. O GP do OS foi inferior aos demais tratamentos avaliados. $\mathrm{O} C R$ do $\mathrm{OA}$ foi inferior aos demais tratamentos, com exceção do OS. O CR do OS mostrou inferior ao OA50/OS50 e OV50/OS50, mas não se diferenciou OV e OA75/OS25. A CA do OA foi melhor a todos os tratamentos. Já para o OV50/OS50 a CA foi pior ao OA75/OS25, sem diferenciar do demais tratamentos. Não houve diferença significativa na VB dos tratamentos. 
Tabela 15. Desempenho de frangos de corte aos 35 dias de idade

\begin{tabular}{ccccc}
\hline Tratamentos & GP $(\mathrm{kg})$ & CR $(\mathrm{kg})$ & CA & VB (\%) \\
\hline OA & $2,026^{\mathrm{a}}$ & $3,121^{\mathrm{c}}$ & $1,52^{\mathrm{a}}$ & $95,4^{\mathrm{a}}$ \\
OS & $1,915^{\mathrm{b}}$ & $3,220^{\mathrm{bc}}$ & $1,67^{\mathrm{bc}}$ & $97,5^{\mathrm{a}}$ \\
OV & $2,038^{\mathrm{a}}$ & $3,396^{\mathrm{ab}}$ & $1,65^{\mathrm{bc}}$ & $96,2^{\mathrm{a}}$ \\
OA75/OS25 & $2,050^{\mathrm{a}}$ & $3,341^{\mathrm{ab}}$ & $1,61^{\mathrm{b}}$ & $97,0^{\mathrm{a}}$ \\
OA50/OS50 & $2,044^{\mathrm{a}}$ & $3,464^{\mathrm{a}}$ & $1,69^{\mathrm{bc}}$ & $98,3^{\mathrm{a}}$ \\
OV50/OS50 & $2,050^{\mathrm{a}}$ & $3,475^{\mathrm{a}}$ & $1,70^{\mathrm{c}}$ & $96,2^{\mathrm{a}}$ \\
CV (\%) & 1,88 & 2,59 & 1,74 & 3,11 \\
\hline a,b,c Diferem estatisticamente na mesma coluna (p>0,05) & &
\end{tabular}

Os valores do ganho de peso, consumo de ração, conversão alimentar e viabilidade aos 42 dias de idade estão apresentados na Tabela 16. Apenas o tratamento OS resultou em um ganho de peso inferior $(P<0,05)$, mostrado desde a primeira semana de criação. O consumo de ração do OS mostrou se inferior aos demais tratamentos. Não diferenças na CA dos tratamentos. Todos os tratamentos mostraram-se condizentes com as EMAn determinadas nas fases de criação, com exceção do OS, que mesmo com os parâmetros de qualidade utilizado para padronizar a matéria-prima, causou perda de desempenho. Vale de alerta, para se pesquisar novas formas de caracterizar a matéria-prima utilizada (gordura) para alimentação de frangos de corte. O uso de valores de energia metabolizável adequadas na formulação das dietas permite que diferentes gorduras ou suas misturas possam ser fornecidas sem perda de desempenho. Além disso, em virtude do ganho energético resultante da mistura $50 \%$ OA com $50 \%$ OS, a quantidade de gordura suplementada pode ser reduzida obtendo-se o mesmo desempenho das aves. Mortalidade ocorrida na última semana de criação concorreu para a menor viabilidade do tratamento $O A(p<0,05)$. 
Tabela 16. Desempenho de frangos de corte aos 42 dias de idade

\begin{tabular}{lcccc}
\hline Tratamentos & GP $(\mathrm{kg})$ & CR(kg) & CA & VB (\%) \\
\hline OA & $2,652^{\mathrm{a}}$ & $4,496^{\mathrm{a}}$ & $1,69^{\mathrm{a}}$ & $92,5^{\mathrm{b}}$ \\
OS & $2,502^{\mathrm{b}}$ & $4,163^{\mathrm{b}}$ & $1,66^{\mathrm{a}}$ & $94,5^{\mathrm{ab}}$ \\
OV & $2,680^{\mathrm{a}}$ & $4,540^{\mathrm{a}}$ & $1,69^{\mathrm{a}}$ & $97,0^{\mathrm{ab}}$ \\
OA75/OS25 & $2,688^{\mathrm{a}}$ & $4,536^{\mathrm{a}}$ & $1,68^{\mathrm{a}}$ & $96,2^{\mathrm{ab}}$ \\
OA50/OS50 & $2,668^{\mathrm{a}}$ & $4,474^{\mathrm{a}}$ & $1,67^{\mathrm{a}}$ & $98,3^{\mathrm{a}}$ \\
OV50/OS50 & $2,656^{\mathrm{a}}$ & $4,533^{\mathrm{a}}$ & $1,70^{\mathrm{a}}$ & $95,0^{\mathrm{ab}}$ \\
CV (\%) & 1,76 & 1,89 & 1,58 & 3,17 \\
\hline a,b Diferem estatisticamente na mesma coluna $(\mathrm{p}>0,05)$ & &
\end{tabular}

Na Tabela 17 são mostrados o peso em jejum (PJejum), o peso da carcaça (PCar), peso do fígado (PFígado), peso da gordura abdominal acumulada (PGAb), peso do peito (PPei), peso da coxa (PCox) e sobrecoxa (PSob).

Não houve diferença significativa entre os tratamentos para o peso dos frangos em jejum (PJejum). O peso da carcaça (PCar) do OV foi superior ao OS, mas não se diferenciou dos demais tratamentos. Não foram encontradas diferenças significativas no peso do fígado (PFígado) e da gordura abdominal acumulada (PGAb), contrapondo os resultados encontrados por Crespo \& Esteve-Garcia (2001), que encontraram diferenças no acúmulo de gordura para diferentes tipos de gordura. Vale ressaltar que estes autores simplesmente adicionaram gordura às dietas (6 e 10\%) sem considerar a energia contida nas diferentes gorduras, com isso provocaram alterações na relação proteína-energia. O método de suplementação das gorduras considerando apenas um valor de energia para avaliar o acúmulo de gordura, resulta em falsas conclusões.

O peso do peito (PPei), da coxa (PCox) e o da sobrecoxa (PSob) do OV foi significativamente $(p<0,05)$ superior ao OS, mas sem se diferenciar dos demais tratamentos. O reflexo da inferior energia fornecida pelo OS na 
criação dos frangos resultou na menor produção de proteína pela ave, mostrados pelo menor peso da carcaça, peito, coxa e sobrecoxa. Neste caso, não houve redução da gordura abdominal acumulada, o que leva a questionar a redução da relação energia-proteína para produção de animais com menos gordura não afetaria a produção de proteína em termos de quantidade.

Tabela 17. Peso da carcaça e partes de frangos de corte alimentados com gorduras

\begin{tabular}{lccccccc}
\hline Tratamentos & PJejum & $\begin{array}{c}\text { PCar } \\
(\mathrm{kg})\end{array}$ & $\begin{array}{c}\text { PFígado } \\
(\mathrm{g})\end{array}$ & $\begin{array}{c}\text { PGAb } \\
(\mathrm{g})\end{array}$ & $\begin{array}{c}\text { PPei } \\
(\mathrm{g})\end{array}$ & $\begin{array}{c}\text { PCox } \\
(\mathrm{g})\end{array}$ & $\begin{array}{c}\text { PSob } \\
(\mathrm{g})\end{array}$ \\
\hline OA & $2,573^{\mathrm{ab}}$ & $1,826^{\mathrm{ab}}$ & $51,0^{\mathrm{a}}$ & $49,3^{\mathrm{a}}$ & $649^{\mathrm{ab}}$ & $265^{\mathrm{ab}}$ & $317^{\mathrm{ab}}$ \\
OS & $2,466^{\mathrm{a}}$ & $1,747^{\mathrm{b}}$ & $49,1^{\mathrm{a}}$ & $40,7^{\mathrm{a}}$ & $608^{\mathrm{b}}$ & $262^{\mathrm{b}}$ & $295^{\mathrm{b}}$ \\
OV & $2,683^{\mathrm{a}}$ & $1,930^{\mathrm{a}}$ & $51,0^{\mathrm{a}}$ & $49,0^{\mathrm{a}}$ & $690^{\mathrm{a}}$ & $283^{\mathrm{a}}$ & $340^{\mathrm{a}}$ \\
OA75/OS25 & $2,595^{\mathrm{ab}}$ & $1,832^{\mathrm{ab}}$ & $50,0^{\mathrm{a}}$ & $44,4^{\mathrm{a}}$ & $644^{\mathrm{ab}}$ & $272^{\mathrm{ab}}$ & $322^{\mathrm{ab}}$ \\
OA50/OS50 & $2,562^{\mathrm{ab}}$ & $1800^{\mathrm{ab}}$ & $50,5^{\mathrm{a}}$ & $43,8^{\mathrm{a}}$ & $645^{\mathrm{ab}}$ & $268^{\mathrm{ab}}$ & $315^{\mathrm{ab}}$ \\
OV50/OS50 & $2,608^{\mathrm{ab}}$ & $1841^{\mathrm{ab}}$ & $50,2^{\mathrm{a}}$ & $48,5^{\mathrm{a}}$ & $663^{\mathrm{a}}$ & $270^{\mathrm{ab}}$ & $325^{\mathrm{ab}}$ \\
CV (\%) & 3,44 & 3,91 & 4,60 & 16,5 & 4,43 & 3,66 & 5,36
\end{tabular}

${ }^{a, b}$ Diferem estatisticamente na mesma coluna $(p>0,05)$

Quando estes valores são transformados em rendimento em relação ao peso de abate as diferenças não se apresentam significativas. $\mathrm{Na}$ Tabela 18 são apresentados os rendimentos relativos ao peso vivo no abate da carcaça (RCar), do fígado (Fígado), a porcentagem gordura abdominal acumulada (\%GAb), o rendimento do peito (RPei), o rendimento da coxa (RCox) e o rendimento da sobrecoxa (RSob). Não houve diferença significativa em termos de rendimento para todos os parâmetros avaliados, concordando com Junqueira et al. (2002). 
Tabela 18. Rendimento de carcaça e partes de frangos de corte (\%) alimentados com gorduras

\begin{tabular}{lcccccc}
\hline Tratamentos & RCar & Fígado & \%GAb & RPei & RCox & RSob \\
\hline OA & $71,0^{\mathrm{a}}$ & $2,80^{\mathrm{a}}$ & $2,69^{\mathrm{a}}$ & $35,5^{\mathrm{a}}$ & $14,5^{\mathrm{a}}$ & $17,4^{\mathrm{a}}$ \\
OS & $71,9^{\mathrm{a}}$ & $2,81^{\mathrm{a}}$ & $2,30^{\mathrm{a}}$ & $34,8^{\mathrm{a}}$ & $15,0^{\mathrm{a}}$ & $16,9^{\mathrm{a}}$ \\
OV & $70,8^{\mathrm{a}}$ & $2,64^{\mathrm{a}}$ & $2,54^{\mathrm{a}}$ & $35,7^{\mathrm{a}}$ & $14,6^{\mathrm{a}}$ & $17,6^{\mathrm{a}}$ \\
OA75/OS25 & $70,6^{\mathrm{a}}$ & $2,73^{\mathrm{a}}$ & $2,42^{\mathrm{a}}$ & $35,1^{\mathrm{a}}$ & $14,8^{\mathrm{a}}$ & $17,5^{\mathrm{a}}$ \\
OA50/OS50 & $70,2^{\mathrm{a}}$ & $2,81^{\mathrm{a}}$ & $2,43^{\mathrm{a}}$ & $35,8^{\mathrm{a}}$ & $14,9^{\mathrm{a}}$ & $17,5^{\mathrm{a}}$ \\
OV50/OS50 & $70,6^{\mathrm{a}}$ & $2,72^{\mathrm{a}}$ & $2,65^{\mathrm{a}}$ & $36,0^{\mathrm{a}}$ & $14,6^{\mathrm{a}}$ & $17,7^{\mathrm{a}}$ \\
CV (\%) & 1,88 & 4,38 & 15,17 & 2,52 & 2,70 & 3,49
\end{tabular}

${ }^{a, b}$ Diferem estatisticamente na mesma coluna $(p>0,05)$

O tratamento com OS mostrou-se inferior no desempenho desde a primeira semana de idade, provavelmente pela inferior qualidade da gordura utilizada no experimento, mesmo que não detectadas com as análises qualitativas feitas, evidenciando que a energia provida pelas gorduras de baixa qualidade afeta o desempenho e a produção de carne de frangos de corte.

\subsection{Conclusões}

A qualidade da gordura afeta o desempenho e a produção de carne de frangos de corte. A utilização de valores energéticos adequados das gorduras não altera o desempenho e o rendimento da carcaça de frangos de corte. 


\section{CONCLUSÕES GERAIS}

Os valores de energia metabolizável aparente e energia metabolizável aparente corrigida para nitrogênio determinados nos experimentos 1 e 2 podem ser utilizados como referência nas formulações de rações, com a vantagem de ajustar os valores de energia metabolizável para as fases préinicial, inicial, crescimento e final de frangos de corte.

No experimento 3 o tratamento com óleo de soja mostrou inferioridade no desempenho desde a primeira semana de idade evidenciando que a qualidade da gordura afeta o desempenho e a produção de carne de frangos de corte. A utilização de valores energéticos adequados das gorduras, não alteram o desempenho e o rendimento da carcaça de frangos de corte. 


\section{REFERÊNCIAS BIBLIOGRÁFICAS}

ANDREOTTI, M.O.; JUNQUEIRA, O. M.; BARBOSA, M.J.B.;et al. Valor energético de algumas fontes de gordura determinado com frangos de corte. (compact disc) In: REUNIÃO ANUAL DA SOCIEDADE BRASILEIRA DE ZOOTECNIA, 37, Viçosa, 2000; Anais. Viçosa: SBZ, 2000.

ARTMAN, N.R. Interactions of fats and fatty acids as energy sources for the chick. Poultry Science, v. 43, p.994-1001, 1964.

BLANCH, A.; BARROETA, A. C.; BAUCELLS, M. D.; et al. The nutritive value of dietary fats in relation to their chemical composition. Apparent fat availability na metabolizable energy in two week old chicks. Poultry Science, v.74, p.1335 - 1340, 1995.

BRUE, R.N.; LATSHAW, J.D. Energy utilization by the chicken as affected by various fats and fat levels. Poultry Science, v.64, p.2119 - 2130, 1985.

CARDOSO, C.C.; GOMES, P.C.; ROSTAGNO, H.S.; et al. Determinação da energia metabolizável de alguns óleos e gorduras para pintos de corte de 21 a 30 dias de idade. (compact disc) In: REUNIÃO ANUAL DA SOCIEDADE BRASILEIRA DE ZOOTECNIA, 37, Viçosa, 2000; Anais. Viçosa: SBZ, 2000. 
CAREW, L.B.; MANCHEMER, R.M.; SHARP, R.W.; et al. Fat absorption by the very young chick. Poultry Science, v.51, p. 738 - 742, 1972.

CRESPO, N.; ESTEVE-GARCIA, E. Dietary fatty acid profile modifies abdminal fat deposition in broiler chickens. Poultry Science, v.80, p.7178, 2001.

DEATON, J.W.; LOTT, B.D. Age and dietary effect on broiler abdominal fat deposition. Poultry Science, v. 64, p.2161-2164, 1985.

DUTRA JUNIOR., W.M.; ARIKI, J.; KRONKA, S.N.; et al. Níveis do óleo de abatedouro avícola no desempenho e características da carcaça de frangos de corte . Revista da Sociedade Brasileira de Zootecnia, v.20, p.476-482, 1991.

DZIEZAK, J.D. Fats, oils, and substitutes. Food Technology, v. 131, p.6674, 1989.

EDWARDS JUNIOR., H.E.; DENMAN, F.; ASHOUR, A.A.; et al. Carcass composition studies. 1. Influences of age, sex and type of dietary fat supplementation on total carcass and fatty acid composition. Poultry Science, v. 52, p.934-948, 1973.

EICHENER, G.; VIEIRA, S.L.; VIOLA, E.S.; et al. Desempenho, rendimento de carcaça e umidade de cama de frangos de corte consumindo dietas formuladas com óleo ácido de soja. Revista Brasileira de Ciência Avícola, supl 6, p.62, 2004. 
GAIOTTO, J.B.; MENTEN, J.F.M.; RACANICCI, A.M.C.; et al. Óleo de soja, óleo ácido de soja e sebo bovino como fontes de gordura em rações de frangos de corte. Revista Brasileira de Ciência Avícola, v.2, n.3, p.219 $-227,2000$.

GOMEZ, M.X.; POLIN, D. The use of bile salts to improve absorption of tallow in chicks, one to three weeks of age. Poultry Science, v.55, p.2189-2195, 1976.

GUNSTONE, F.D; HARWOOD, J.L; PADLEY, F.B. The Lipid Handbook. 2. ed. New York: Chapman and Hall, 1994. 1273p.

GURR, M.I; HARWOOD, J.L. Lipid Biochemistry. 4. ed. New York: Chapman and Hall, 1991. 404p.

HYVÖNEN, L. Approach to fat analysis of foods. Food Chemistry, v. 57, p.23-26, 1996.

JUNQUEIRA, O.M.; ANDREOTTI, M.O.; CANCHERINI, L.C.; et al. Rendimento de carcaças e composição corporal de frangos de corte alimentados com rações isoenergéticas formuladas com diferentes níveis de óleo de soja. (compact disc) In: REUNIÃO ANUAL DA SOCIEDADE BRASILEIRA DE ZOOTECNIA, 39, Recife, 2002; Anais. Recife: SBZ, 2000.

KATONGOLE, J.B.D; MARCH, B.E. Fat utilization in relation to intestinal fatty acid binding protein and bile salts in chicks of different genetic sources. Poultry Science, v. 59, p.819-827, 1980. 
KEREN-ZVI, S.; NIR, Z.; NITSAN, Z.; et al. Effect of dietary concentratins of fat and energy on fat deposition in brolirer divergently selected for high or low abdominal adipose tissue. Bristish. Poultry Science, v. 31, p.507516, 1990.

KETELS, E.; DE GROOTE, G. The nutritional value for broiler of fats characterized by short chain fatty acids as affected by level of inclusion and age. Animal Feed Science and Technology, v. 22, p.105-118, 1988.

KETELS, E.; DE GROOTE, G. Effect of ratio of unsaturated to saturaded fatty acids of the dietary lipid fraction on utilization and metabolizable energy of added fats in young chicks. Poultry Science, v.68, p.1506 $1512,1989$.

KROGDAHL, A. Digestion and absorption of lipid in poultry. Journal of Nutrition, v.115, p.675-685, 1985.

LESSON, S; SUMMERS, J.D. Scott's nutrition of the chicken. 4. ed. Guelph: University Books, 2001. 380p.

LIU, K. Soybeans: chemistry, technology and utilization. New York: Chapman and Hall, 1999. 532p.

MACARI, M. Fisiologia aviária aplicada a frangos de corte. Jaboticabal: FUNEP/UNESP, 2002. 375p.

MAFFI, G.L. Graxarias e subprodutos. In: CONFERÊNCIA APINCO DE CIÊNCIA E TECNOLOGIA AVÍCOLAS. Campinas, 1993. Anais. Campinas:FACTA, 1993, p.191-201. 
MATEOS, G.G.; SELL, J.L. True and apparent metabolizable energy value of fat for laying hens: influence of level of use. Poultry Science, v. 59, p.369-373, 1980

MATEOS, G.G.; SELL, J.L. Metabolizable energy of supplemental fat as related to dietary fat level and methods of estimation. Poultry Science, v. 60, p.1509-1515, 1981.

MATTERSON, L.D; POTTER L.M; STUTZ, N.W; SINGSEN, E.P. The metabolizable energy of feed ingredients for chicks. Research Report, v.7, p.3-11, 1965.

MOSSAB, A; HALLOUIS, J.M; LESSIRE, M. Utilization of soybean oil and tallow in young turkeys compared with young chickens. Poultry Science, v. 79, p.1326-1331, 2000.

NATIONAL RESEARCH COUNCIL. Nutrient requirements of poultry. 9. ed. Washington, D. C.: National Academy Press, 1994. 71p.

NELSON, D.L; COX M.M. Lehninger principles of biochemistry. 3. ed. NewYork: Worth Publishers, 2000. 1152p.

NETO, G.J. Abate e processamento de frangos. Campinas:FACTA, 1994. $150 p$.

NOY, Y.; SKLAN, D. Digestion and absorption in the young chick. Poultry Science, v.7, p.366 - 373, 1995. 
NOY, Y.; SKLAN, D. Hidrolysis and absorption in the small intestines od posthatch chicks. Poultry Science, v.79, p.1306-1310, 2000.

PENZ JUNIOR., A. M.; VIEIRA, S.L. Nutrição na primeira semana. In: CONFERÊNCIA APINCO'98 DE CIÊNCIA E TECNOLOGIA AVÍCOLAS, Campinas, 1998. Anais. Campinas: FACTA, 1998. p. 121-138.

PIGNOL, D; HERMOSO, J; KERFELEC, B; et al. The lipase/colipase complex is activated by a micelle: neutron crystallographic evidence. Chemistry and Physics of Lipids, v. 93, p.123-129, 1998.

RENNER, R.; HILL, F.W. Factors affecting the absorbability of sturated fatty acids in the chick. Journal of Nutrition, v.74, p.254-258, 1961.

ROSTAGNO, H.S; ALBINO, L.F.T.; DONZELE, J.L. et al. Tabelas brasileiras para aves e suínos: Composição de alimentos e exigências nutricionais. Viçosa: UFV, Departamento Zootecnia, 2000. $141 \mathrm{p}$.

RUIZ-MÉNDEZ, M.V; MÁRQUEZ-RUIZ, G; DOBARGANES, M.C. Relationships between quality of crude and refined oils based on quantification of minor glyceridic compounds. Food Chemistry, v. 60, p.549-554, 1997.

RUTZ, F. Fisiologia da digestão e absorção das aves. Campinas: FACTA, 1994. 176p.

SAS INSTITUTE, SASISTAT user's Guide, version 6, Cary,1989. 956p. 
SIBBALD, I.R. Measurement of bioavailable energy in poultry feedingstuffs: a review . Canadian Journal of Animal Science, v. 62, p. 983-1047, 1982.

SIBBALD, I.R.; SLINGER, S.J. A biological assay for metabolizable energy in poultry feed ingredients together with findings which demonstrate some of the problems associated with the evaluation of fats. Poultry Science, v.42, p.313 - 325, 1963.

SIBBALD, I.R.; KRAMER, J.K.G. Effect of the basal diet on the utilization of fat as a sources of true metabolizable energy, lipid and fatty acid. Poultry Science, v. 59, p. 316-324, 1980a.

SIBBALD, I.R.; KRAMER, J.K.G. The effects of fractions of yellow corn on the true metabolizable energy value of beef tallow. Poultry Science, v. 59 , p. $1505-1509,1980 b$.

SIBBALD, I.R.; SLINGER, S.J.; ASHTON, G.C. Factors affeting the metabolizable energy content of poultry feeds. 2. Variability in the M.E. values attributed to samples of tallow, and undeummed soybean oil. Poultry Science, v.40, p.303 - 308, 1961.

SILVA, D.J. Análise de alimentos (Métodos químicos e biológicos). 2. ed. Viçosa: UFV, Imprensa Universitária, 1990. 165p.

TUCHWEBER, B; YOUSEF, I.M; FERLAND, G; et al. Nutrition and bile formation. Nutrition Research v. 16, p.1041-1080, 1996.

VAN TILBEURGH, H; SARDA, L; VERGER, R; et al. Structure of the pancreatic lipase-procolipase complex. Nature, v. 359, p.159-162, 1992. 
VAN TILBEURGH, H; EGLOFF, M; MARTINEZ, C; et al. Interfacial activation of the lipase-procolipase complex by mixed micelles revealed by X-ray crystallography. Nature, v. 362, p.814-820, 1993.

VAN TILBEURGH, H; BEZZINE, S; CAMBILLAU, C.; et al. Colipase: structure and interaction with pancreatic lipase. Biochimica et Biophysica Acta, v. 1441, p.173-184, 1999.

VILA, B.; GARCIA, E.E. Studies on acid oils and fatty acids for chickens. III. Effect of chemical composition on metabolizable energy of by-products of vegetable oil refining. British Poultry Science, v.37, p.131-144, 1996.

WALDROUP, P. W.; WATKINS, S. E.; SALEH, E. A. Comparison of two blended animal-vegetable fats having low or high free fatty acid content. Journal of Applied Poultry Research, v. 4, p. 41-48, 1995.

WINKLER, F.K; D'ARCY, A; HUNZIKER, W. Structure of human pancreatic lipase. Nature, v. 343, p.771-774, 1990.

WISEMAN, J.; SALVADOR, F. Influence of age, chemical composition and rate of inclusion on the apparent metabolizable energy of fats fed to broiler chicks. British Poultry Science, v.30, p.653 - 662, 1989.

WISEMAN, J.; SALVADOR, F. The influence of free fatty acid content and degree of saturation on the apparent metabolizable energy value of fats fed to broilers. Poultry Science, v. 70, p. $573-582,1991$. 
WISEMAN, J.; COLE, D.J.A.; PERRY, F.G.; et al. Apparent metabolizable energy values of fats for broiler chicks. Bristish Poultry Science, v. 27, p.561-576, 1986.

YOUNG, R. J. The energy value of fats and fatty acids for chicks. 1.Metabolizable energy. Poultry Science, v. 40, p. 1225 - 1233, 1961.

YOUNG, R.J.; ARTMAN N.R. The energy value of fats and fatty acids for chicks. 2. Evaluted by controlled feed intake. Poultry Science, v. 40, p.1653-1662, 1961.

YOUNG, R. J.; GARRETT, R. L. Effect of oleic and linoleic acids on the absorption of saturated fatty acids in the chick. Journal of Nutrition, v.81, p.321-329, 1963.

ZAMBIAZI, R.C; ZAMBIAZI, M. Vegetable oil oxidation: effect of endogenous components. Boletim da Sociedade Brasileira de Ciência e Tecnologia de Alimentos, v. 34, p. 22-32, 2000.

ZOLLITSCH, W.; KNAUS, W.; AICHINGER, F.; et al. Effects of different dietary and carcass characteristics of broiler. Animal Feed Science and Technology, v.66, p.63-73, 1997.

ZUMBADO, E.M.; SCHEELE, C.R.; KWAKERNAAK, C. Chemical composition, digestibility, and metabolizeble energy content of different fat and oil by-products. Journal Applied Poultry Research, v.8, p.263 $271,1999$. 